\title{
Interannual Rainfall Variability in the Tropical Atlantic Region
}

\author{
Guojun $\mathrm{Gu}$
}

Goddard Earth Sciences and Technology Center, University of Maryland

Baltimore County, and Laboratory for Atmospheres, NASA/Goddard Space

Flight Center, Greenbelt, MD, USA.

Robert F. Adler

Laboratory for Atmospheres, NASA/Goddard Space Flight Center, Greenbelt, MD, USA.

Guojun Gu, Code 912, Goddard Space Flight Center, Greenbelt, MD 20771, USA. (ggu@agnes.gsfc.nasa.gov)

Robert F. Adler, Code 912, Goddard Space Flight Center, Greenbelt, MD 20771 , USA. (adler@agnes.gsfc.nasa.gov) 
2 GU AND ADLER: INTERANNUAL RAINFALL VARIABILITY IN THE TROPICAL ATLANTIC REGION

Abstract. Rainfall variability on seasonal and interannual-to-interdecadal time scales in the tropical Atlantic is quantified using a 25-year (1979-2003) monthly rainfall dataset from the Global Precipitation Climatology Project (GPCP). The ITCZ measured by monthly rainfall between $15^{\circ}-37.5^{\circ} \mathrm{W}$ attains its peak as moving to the northernmost latitude $\left(\sim 8^{\circ}-10^{\circ} \mathrm{N}\right)$ during July-September in which the most total rainfall is observed in the tropical Atlantic basin $\left(17.5^{\circ} S-22.5^{\circ} N, 15^{\circ}-37.5^{\circ} \mathrm{W}\right)$; the ITCZ becomes weakest during January-February with the least total rainfall as it moves to the south. In contrast, rainfall variability on interannual to interdecadal time scales shows a quite different seasonal preference. The most intense interannual variability occurs during March-May when the ITCZ tends to be near the equator and becomes weaker. Significant, negative correlations between the ITCZ strength and latitude anomalies are observed during boreal spring and early summer.

The ITCZ strength and total rainfall amount in the tropical Atlantic basin are significantly modulated by the Pacific El Niño and the Atlantic equatorial mode (or Atlantic Niño) particularly during boreal spring and summer; whereas the impact of the Atlantic interhemispheric mode is considerably weaker. Regarding the anomalous latitudes of the ITCZ, the influence can come from both local, i.e., the Atlantic interhemispheric and equatorial modes, and remote forcings, i.e., El Niño; however, a direct impact of El Niño on the latitudes of the ITCZ can only be found during April-July, not in winter and early spring in which the warmest SST anomalies are usually observed in the equatorial Pacific. 


\section{Introduction}

Tropical convection and rainfall in the Atlantic basin exhibit intense variations on various time scales [e.g., Nobre and Shukla, 1996; Giannini et al., 2001a, b; Chiang et al., 2000; Chiang et al., 2002]. A narrow band of deep convection and rainfall manifesting the Atlantic Intertropical Convergence Zone (ITCZ) is usually observed north of the equator with the northeasterly and southesterly trade winds converging into it. This narrow band of rainfall or the ITCZ appears primarily over open ocean, but extends to the northeast coast of tropical South America during boreal spring and to the West African continent in boreal summer, roughly following the seasonal movement of warm sea surface temperature (SST) $\left(\geq 27^{\circ} \mathrm{C}\right)$ [Figure 1]. The fluctuations in the ITCZ's intensity and location may thus be closely connected to rainfall variability both in the tropical Atlantic basin and over the two neighboring continents [e.g., Nobre and Shukla, 1996; Grist and Nicholson, 2001]. Exploring the ITCZ variability can hence provide a reasonable and feasible perspective to Atlantic climate variability regarding the ITCZ-associated convection and rainfall and atmospheric circulation anomalies.

Previous studies showed a close link between the anomalies in the strength and latitude of the Atlantic ITCZ and global SST anomalies [e.g., Hastenrath and Greischar, 1993; Nobre and Shukla, 1996; Uvo et al., 1998; Giannini et al., 2001b]. Two anomalous SST patterns in the tropical Atlantic are considered to be the major local forcings on interannual to interdecadal time scales [e.g., Carton and Huang, 1994; Enfield et al., 1999; Servin et al., 1999]. The first is similar to, but much weaker than the Pacific El Niño, and occurs near the equator and peaks primarily during boreal summer [e.g., Zebiak, 1993; Carton and Huang, 1994; Ruiz-Barradas et al., 2000]. A southward shift of convection and 
4 GU AND ADLER: INTERANNUAL RAINFALL VARIABILITY IN THE TROPICAL ATLANTIC REGION rainfall occurs during the warm phase of the event with evident atmospheric circulation anomalies [e.g., Ruiz-Barradas et al., 2000; Wang, 2002], e.g., weaker trade winds in the tropical western Atlantic, and a weakened Atlantic Walker cell but a strengthened local Hadley cell. This SST anomaly feature is usually named the Atlantic equatorial mode or the Atlantic Niño despite that it is a damped mode unlike the Pacific El Niño [Zebiak, 1993], and may itself be strongly modulated by the tropical Pacific [e.g., Delecluse et al., 1994; Latif and Grötzner, 2000]. The second SST anomaly pattern is characterized as an out-of-phase SST anomaly between two regions: one is the northern tropical Atlantic $\left(5^{\circ}-25^{\circ} N\right)$ and the other the southern tropical Atlantic $\left(5^{\circ}-25^{\circ} S\right)$. This out-of-phase SST anomaly is manifested as a cross-equatorial SST gradient reaching its maximum in boreal spring [e.g., Hastenrath and Greischar, 1993; Nobre and Shukla, 1996], though the causal relations within this dipole-like phenomenon have been statistically challenged [e.g., Houghton and Tourre, 1992; Enfield et al., 1999]. As: a dominant interdecadal oscillation in the tropical Atlantic [e.g., Ruiz-Barradas et al., 2000], this SST gradient mode might effectively impact the migration of the Atlantic ITCZ [e.g., Nobre and Shukla, 1996]. Anomalously warm (cold) north/cold (warm) south SST configuration could induce an anomalous northward (southward) shift of the ITCZ and then cause drought (flood) in northeast tropical South America [e.g., Wagner, 1996].

In addition to the local SST modes, two other remote forcings have also been recognized [e.g., Deque and Servin, 1989; Curtis and Hastenrath, 1995; Enfield and Mayer, 1997; Xie and Tanimoto, 1998]: (i) The North Atlantic Oscillation (NAO) and related atmospheric circulation anomaly in the higher latitudes had shown impact on the tropical Atlantic SST and atmospheric large-scale circulations [e.g., Deque and Servin, 1989; Xie and Tanimoto, 
GU AND ADLER: INTERANNUAL RAINFALL VARIABILITY IN THE TROPICAL ATLANTIC REGION 5 1998; Wang, 2002], while this impact was not consistently confirmed by other studies [e.g., Ruiz-Barradas et al., 2000]. (ii) The Pacific El Niño event can have influence on the Atlantic ITCZ and the SST in the northern tropical Atlantic [e.g., Curtis and Hastenrath, 1995; Enfield and Mayer, 1997; Ruiz-Barradas et al., 2000]. Two distinct mechanisms were proposed [e.g., Chiang et al., 2002]. One is the Pacific-North-American atmospheric teleconnection (PNA) passing through the midlatitudes [e.g., Nobre and Shukla, 1996]. Anomalous SST warming often appears in the north tropical Atlantic about one season after the peak month of El Niño, likely caused by weakened trade winds. The other is the anomalous Walker circulation forced directly by diabatic heating anomalies in the tropical Pacific [e.g., Saravanan and Chang, 2000; Chiang et al., 2002]. Anomalous warm (cold) tropospheric temperatures following the warm (cold) ENSO spread across the tropical troposphere, and tends to stabilize (disturb) the atmosphere and hence suppress (enhance) precipitation in the tropical Atlantic [e.g., Chiang et al., 2002; Chiang and Sobel, 2002].

Chiang et al. [2002] mentioned both mechanisms related to El Niño, and showed that a strong anomalous Walker cell during the El Niño causes negative rainfall anomalies in the tropical Atlantic. Local SST gradient mode was also discussed in their study. An anomalous warm north/cool south SST pattern manifesting a strong northward SST gradient can effectively shift the Atlantic ITCZ to the north. The physical pictures associated with these changes were explored by further documenting the ITCZ variability's seasonal dependence, sensitivity to small anomalous SST gradients, and possible modulations of the SST anomalies. The most interesting part in their work is that the variations of Atlantic ITCZ quantified by monthly precipitation, rather than SST anomalies as in most previous 
6 GU AND ADLER: INTERANNUAL RAINFALL VARIABILITY IN THE TROPICAL ATLANTIC REGION

studies [e.g., Curtis and Hastenrath, 1995; Nobre and Shukla, 1996; Sutton et al., 2000], are concentrated.

Chiang et al. [2002] however did not discuss the role of the Atlantic equatorial mode in the ITCZ variability. They primarily focused on the boreal spring in which the most intense interannual to interdecadal variability is usually found. The Atlantic equatorial mode usually becomes active during boreal late spring and summer, and modulates convection and rainfall in the equatorial region [e.g., Sutton et al., 2000; Ruiz-Barradas et al., 2000]. Also, intense tropical weather and rainfall systems, such as African easterly waves and tropical cyclones, frequently appear along the Atlantic ITCZ during boreal summer. These systems have shown evident interannual variability [e.g., Thorncroft and Rowell, 1998; Landsea et al., 1999; Gu et al., 2003]. Hence quantifying rainfall variability, especially the ITCZ variablity during boreal summer and fall may provide some clues to understanding these variabilities, specifically the variability in West African Monsoon system and Atlantic hurricane activity [e.g., Janicot et al., 1998; Landsea et al., 1999].

Therefore, instead of only focusing on boreal spring, rainfall variability in all seasons will be investigated here. We focus our attention on interannual rainfall variability in the tropical Atlantic and particularly the Atlantic ITCZ-related variability. Seasonal dependence will be explored according to the dominant local and remote SST forcing modes. Our objectives are (1) to document the correlations between rainfall and SST modes, (2) to investigate the seasonal dependence of rainfall variability, and (3) hence to explore physical mechanisms that may explain the major features of the Atlantic ITCZ on the interannual to interdecadal time scales. 
GU AND ADLER: INTERANNUAL RAINFALL VARIABILITY IN THE TROPICAL ATLANTIC REGION 7

The datasets used in this study are introduced in section 2. Seasonal rainfall variation in the tropical Atlantic is described in section 3. Rainfall variability on the interannual time scale is then quantified with a specific focus on the Atlantic ITCZ represented by monthly rainfall. The relationships between rainfall and SST anomalies are investigated in section 4. Summary and discussions are given in section 5 .

\section{Data}

A 25-year (1979-2003) monthly mean rainfall dataset from the Global Precipitation Climatology Project (GPCP) is used to quantify the Atlantic ITCZ and rainfall variability: On a global $2.5^{\circ} \times 2.5^{\circ}$ grid, the data is combined from various information sources [Adler et al., 2003]: the infrared (IR) rainfall estimates from geostationary and polar-orbiting satellites, the microwave estimates from Special Sensor Microwave/Imager (SSM/I), and surface rain gauges from the Global Precipitation Climatological Centre (GPCC).

The SST anomalies and related SST modes in both the tropical Atlantic and Pacific Oceans are estimated using a 22-year (1982-2003) monthly mean SST dataset [Reynolds and Smith, 1994]. This dataset is archived on $1^{\circ} \times 1^{\circ}$ grids.

\section{Variability and Structure of Rainfall Anomalies}

\subsection{Seasonal Variation}

Seasonal mean rainfall in the tropical Atlantic basin and neighboring continents is shown in [Figure 1] together with the seasonal mean SST. A narrow band of rainfall over open ocean manifesting the marine ITCZ can be seen year-round, roughly over the regions with higher SST $\left(\geq 27^{\circ} \mathrm{C}\right)$. During boreal winter and spring, the marine ITCZ is weaker and located near the equator. It becomes much stronger in boreal summer and fall as it 
8 GU AND ADLER: INTERANNUAL RAINFALL VARIABILITY IN THE TROPICAL ATLANTIC REGION

moves away from the equator to reach its northernmost position, concomitant with the occurrence of an equatorial cold tongue. Interestingly, the warmest SSTs however occur during March-May. Particularly, the warm SSTs $\left(\geq 29^{\circ} C\right)$ in the eastern Atlantic basin (east of about $10^{\circ} \mathrm{W}$ ) during this season correspond to the peak rainfall season near the Gulf of Guinea in June [e.g., Gu and Adler, 2004].

Seasonal variations of rainfall are evident over land. Convection and rainfall over West Africa (west of about $10^{\circ} \mathrm{E}$ ) show a quite similar seasonal cycle as the marine ITCZ. No significant rainfall occurs during boreal winter, though a weak rainy zone is located in the eastern tropical Atlantic connecting the marine ITCZ and the large area of rainfall over the southern part of the African continent. Convection and rainfall peak in boreal summer over West Africa. A similar seasonal cycle existing in rainfall over West Africa as in the marine ITCZ probably suggests a strong seasonal modulation by the Atlantic Ocean in addition to other factors such as land surface forcing. Using recently-archived satellite observations, $G u$ and Adler [2004] detailed the seasonal evolution pattern of the entire coupled system in the tropical eastern Atlantic and West Africa, and emphasized the influence of SST and its related dynamic forcing on seasonal rainfall variability near the Gulf of Guinea.

Convection and rainfall over tropical South America, however, exhibit a quite different seasonal-evolution pattern likely due to distinct geographical configurations. Most intense convection and rainfall appear during boreal winter, covering a large area of the continent mostly south of the equator; the major rainfall area gradually moves to the north forced by the seasonal march of insolation on the earth; convection and rainfall become weaker in boreal summer and fall as the major rainy zone approaches and crosses the equator; in 
GU AND ADLER: INTERANNUAL RAINFALL VARIABILITY IN THE TROPICAL ATLANTIC REGION 9 particular, a narrow east-west band structure of rainfall can not consistently be observed, showing a rainfall pattern distinct from the marine ITCZ. Thus, seasonal march of rainfall over South America might primarily be controlled by land-surface processes as expected, whereas the oceanic impact may become important during boreal spring in which the marine ITCZ moves close to the equator and becomes more connected with convection over land.

To limit the effects of land-surface processes, here we primarily focus on the marine ITCZ defined by mean rainfall between $15^{\circ} \mathrm{W}-37.5^{\circ} \mathrm{W}$, though the possible impact of convection over land on the marine ITCZ may still exist. The position and strength of the ITCZ are represented by the latitude and magnitude of maximum precipitation, respectively. The basin-mean rainfall $\left(17.5^{\circ} S-22.5^{\circ} \mathrm{N}, 15^{\circ}-37.5^{\circ} \mathrm{W}\right)$ is further calculated to assess the total rainfall variability in the tropical Atlantic basin and for a comparison with the ITCZ strength. The 25-year mean seasonal cycles are then estimated for these three quantities [Figure 2]. Compared to Figure 1, Figure 2 illustrates a more quanti-tative description of seasonal variations in the tropical Atlantic. The ITCZ attains its southernmost (northernmost) position during March-April (July-August). Rainfall intensity represented by both the ITCZ strength [solid line in Figure 2] and basin-mean rainfall [dashed line in Figure 2] reaches their peaks in August, and becomes weakest during January-February. It is interesting to note that the ITCZ strength and basin-mean rainfall generally follow each other, though there is a second peak in May for the latter probably due to a relatively scattered structure of the ITCZ during this time period, particularly in the western tropical Atlantic [Figure 1], and the appearance of a southern branch of the ITCZ [Liu and Xie, 2002; Grodsky and Carton, 2003].

Figure.2

Figure 1

Figure 2

Figure 2

Figure 2

\section{Figure 1}


10GU AND ADLER: INTERANNUAL RAINFALL VARIABILITY IN THE TROPICAL ATLANTIC REGION

\subsection{Interannual-to-Interdecadal Variability}

Seasonal mean interannual variances of rainfall and SST are shown in Figure 3. Most Figure 3 intense variances of precipitation are observed during boreal winter and spring, and tend to be located in the west basin and over the northeast coastal region of South America. During boreal summer, the maximum variance zone moves to the north following the movement of the ITCZ, but becomes relatively weaker than in the earlier seasons. The least rainfall variances are observed during boreal fall. This seasonal evolution pattern is basically consistent with past discoveries [e.g., Hastenrath and Greischar, 1993; Nobre and Shukla, 1996]. Compared to rainfall variances, SST variances tend to be located in the east side of the basin. Furthermore, during boreal winter and spring, no strong variances can be observed near the equator. Evident equatorial SST variances can only be seen during boreal summer, probably corresponding to the anomalous warm/cold events occuring every 2-4 years [e.g., Zebiak, 1993]..SST variances seem to be passive responses to the atmospheric anomalies mostly originating in the western portion of the basin. However, the modulations of rainfall variability by SST anomalies can also be deduced. For instance, intense rainfall variances near the Gulf of Guinea during June-August are clearly reflecting SST variabilities associated with the Atlantic equatorial mode.

To further explore rainfall variability on interannual and/or longer time scales, three anomaly time series corresponding to the ITCZ strength [solid line in Figure 4a], the ITCZ position [Figure 4b], and the basin-main rainfall [dashed line in Figure 4a] are constructed by subtracting their respective mean seasonal cycles, and denoted as $P_{i t c z}, L a t_{i t c z}$, and $P_{d m}$, respectively [Figure 4].

Figure 4a

Figure $4 b$

Figure 4a

Figure 4

\subsubsection{Spectral Decomposition.}


Interannual variability in $P_{i t c z}, L a t_{i t c z}$, and $P_{d m}$ is evident. Global wavelet power spectra are estimated and shown in Figure 5 [Torrence and Compo, 1998]. A strong power peak Figure 5 stands out within a period range of $2-6$ years in these three time series. $P_{i t c z}$ even has two separate power peaks within this period range [solid line in Figure 4]. Two other Figure 4 peaks appear within the period ranges of $1-2$ and $8-11$ years, respectively, but are discernible only in $L a t_{i t c z}$ and $P_{d m}$. These spectral peaks strongly suggest the existence of interannual to interdecadal variability in rainfall as in SST anomalies in the tropical Atlantic [Figure 10a; Tourre et. al, 1999; Latif and Grötzner, 2000]. Further discussions on SST anomalies and possible relations with rainfall variability are given in next section.

Using a wavelet filtering procedure [e.g., Torrence and Compo, 1998], variances of rainfall anomalies in the tropical Atlantic basin are further estimated within three specific period bands, i.e., $1-2,2-6$, and $6-12$ years [Figure 6]. Within the period bands of $1-2$ and $6-12$ years, the variances tend to stay away from: the region of $0-2.5^{\circ} \mathrm{N}$ with one maximum around $5^{\circ} \mathrm{N}$ and the other south of the equator covering part of the coastal region of northeast South America. For the $1-2$ year period band, there is a third maximum just north of the equator along the northeastern coast of South America. In contrast, rainfall variance of $2-6$ years shows a distinct spatial pattern. The large area of variance tends to be concentrated at or just north of the equator, with two major maxima being seen with one over open ocean and the other in the coastal region. Totally different spatial patterns between those corresponding to rainfall variability within the $2-6$ (interannual) and $6-12$ (interdecadal) year periods may imply different physical mechanisms and/or distinct relationships with SST anomalies. Past studies recognized that various SST anomaly features exist on both time scales in the tropical Atlantic [e.g., 
12GU AND ADLER: INTERANNUAL RAINFALL VARIABILITY IN THE TROPICAL ATLANTIC REGION

Tourre et. al, 1999; Ruiz-Barradas et al., 2000]. It is further noted that the northeast

South American region experiences rainfall variability on all three time scales, suggesting a complicated modulation probably by both the Atlantic and Pacific [e.g., Wainer and Soares, 1997; Uvo et al., 1998]. It also needs to be mentioned that the variances within these three period bands are negligible over West Africa compared to those over South America and open ocean. As indicated in Figure 3, evident interannual rainfall variances near Africa can only be seen during June-August and tend to be near the Gulf of Guinea.

\subsubsection{Seasonal Dependence.}

Domain-mean variance of rainfall anomalies $\left(P t_{d m}\right)$ in the tropical Atlantic $\left(17.5^{\circ} S-\right.$ $22.5^{\circ} \mathrm{N}, 15^{\circ}-37.5^{\circ} \mathrm{W}$ ), and variances of $P_{i t c z}$ and $L a t_{i t c z}$ are further depicted in Figure 7 as a function of month. As in Figure 3, evident seasonal dependence is shown, particularly

in variances of $P t_{d m}$ and $L a t_{i t c z}$. For them, the largest (smallest) variances appear during boreal spring (fall), consistent with past results [e.g., Chiang et al., 2002]. However, variance of $P_{i t c z}$ shows a complicated and different seasonal preference. In addition to a peak in April, two other ones occur during January and July-August, respectively. This may imply during these months some large-scale modes appear to modulate the ITCZ intensity, but can not effectively influence the total amount of rainfall and the position of the ITCZ. More discussions will be given in next section.

Chiang et al. [2002] discussed the interdependence between the ITCZ strength and position. The two are significantly, negatively correlated in several months, i.e., January, April, May and July. More (less) rainfall appears as the ITCZ stays farther south (north), quite different from the ITCZ variability on seasonal time scale [Figures 1 and 2]. Because of the strong seasonal dependence of interannual-to-interdecadal variances [Figure 7] and

Figures 1

Figure 7 
GU AND ADLER: INTERANNUAL RAINFALL VARIABILITY IN THE TROPICAL ATLANTIC REGIONI3 a different dataset used here than in Chiang et al. [2002], linear correlations between $P_{i t c z}$ and $L a t_{i t c z}$ [dashed line in Figure 8], and between $P_{d m}$ and $L a t_{i t c z}$ [solid line in Figure 8] are calculated. As expected, significantly negative correlations between $P_{i t c z}$ and $L a t_{i t c z}$ appear during boreal spring. Different than in Chiang et al. [2002], significant correlations can also be seen in July and October. We call this phenomenon the ITCZ's self-correlation. Furthermore, a stronger and more consistent interdependence can be found between $P_{d m}$ and $L_{a t} t_{i t c z}$. The correlation coefficients between these two parameters above the $5 \%$ confidence level last from February to July, which might suggest that anomalous positions of the ITCZ are more associated with basin-mean rainfall anomalies than the ITCZ's strength due to its somewhat scattered structure in these months [Liu and Xie, 2002; Grodsky and Carton, 2003].

\section{Relationships between Rainfall and SST Anomalies}

In last section interannual rainfall variability was examined by a spectrum analysis and a further decomposition into three components within interannual to interdecadal period bands. Here, we are focusing on relating rainfall anomalies in the tropical Atlantic to the known SST modes in both the tropical Pacific and Atlantic.

Three SST anomaly time series are constructed to represent the Pacific El Niño (Nino3) [solid line in Figure 9a], Atlantic Niño (Atl3) [dashed line in Figure 9a], and Atlantic inter-

hemispheric mode (TNA-TSA) [Figure 9b]. These three modes are generally considered to be the major, somewhat competing factors modulating climate variability in the basin

Figure 9a

Figure 9a

Figure 9b [e.g., Servain et al., 1999; Ruiz-Barradas et al., 2000; Wang, 2002]. Nino3 and Atl3 are defined as the mean SST anomalies within the domains of $5^{\circ} \mathrm{S}-5^{\circ} \mathrm{N}, 90^{\circ} \mathrm{W}-150^{\circ} \mathrm{W}$, and $4^{\circ} S-4^{\circ} N, 0^{\circ}-20^{\circ} W$, respectively; TNA-TSA is denoted as the difference of SST anoma- 
14GU AND ADLER: INTERANNUAL RAINFALL VARIABILITY IN THE TROPICAL ATLANTIC REGION lies between the two domains in the tropical Atlantic, i.e., $5^{\circ} \mathrm{N}-25^{\circ} \mathrm{N}, 16^{\circ} \mathrm{W}-56^{\circ} \mathrm{W}$ (tropical north Atlantic), and $5^{\circ} S-25^{\circ} S, 10^{\circ} \mathrm{E}-30^{\circ} \mathrm{W}$ (tropical south Atlantic). TNA $(T S A)$ represents the domain-mean SST anomalies in the tropical north (south) Atlantic.

\subsection{Spectral Decomposition of SST Anomalies}

Prior to exploring the association of rainfall variability with these SST modes, the behaviors of SST anomalies are first decomposed using a wavelet analysis. Wavelet power spectra of the three SST time series and the mean spectrum of the SST anomalies in the tropical Atlantic are shown in Figure 10. For Atl3, two strong power peaks appear within the period bands of $2-6$ (interannual) and 7-12 (interdecadal) years, respectively, with another peak of $1-2$ years (interannual). TNA-TSA shows a different power distribution with two separate peaks in the period band of $2-6$ years, one around 2.5 years and the other around 5 years; also, its interdecadal power peak shifts to about 7.8 years. Mean spectral power of SST anomalies in the tropical Atlantic basin $\left(20^{\circ} \mathrm{S}-20^{\circ} \mathrm{N}, 15^{\circ}-38^{\circ} \mathrm{W}\right)$ shows a similar distribution as for $T N A-T S A$, whereas the mean interdecadal power peak becomes much stronger than its interannual counterparts showing its dominance. These power peaks are generally consistent with past results [e.g., Tourre et al., 1999; Ruiz-Barradas et al., 2000; Andreoli and Kayano, 2004]. In contrast, Nino3 shows only one power peak in the interannual period band [Figure 10b], indicating its preferred single period range of El Niño/La Niña [e.g., Rasmusson and Carpenter, 1982].

Spatial distributions of SST variances within the three period bands are calculated [Figure 11], again based on the wavelet filtering of SST anomalies [e.g., Torrence and Compo, 1998]. Within the 1-2 year period band, two large areas of SST variances are observed. One is north of the equator right off the coast of West Africa; the other is 

mostly south of the equator with a maximum between $10^{\circ} S-20^{\circ} S$ off the African coast. SST variances within the period band of 6-12 years also show two favored regions. One is north of $10^{\circ} \mathrm{N}$ near the West African coastal region; the other is between $0-5^{\circ} \mathrm{S}$, extending from about $25^{\circ} \mathrm{W}$ to the African coast. Interestingly, these two modes tend to stay away from the latitude band of $0-5^{\circ} N$, similar as found in rainfall variances [Figure 6a, c]. Within the 2-6 year band, three major areas of SST variances can be found. The first Figure 6a area is north of the equator and the maximum variance tends to be near the West African coast. The second is south of the equator near the African coast, roughly covering the eastern Atlantic from 0 to $20^{\circ} \mathrm{S}$. The existence of large SST variance of $2-6$ year period in this area, together with the signals within the 1-2 year period might indicate the activity of Benguela Niño discovered in past studies [e.g., Florenchie et al., 2003; Florenchie et al., 2004]. The third large SST variance area is right across the equator with a maximum at about $10^{\circ} \mathrm{W}$. Compared to previous results [e.g., Ruiz-Barradas et al., 2000], this mode might be the dominant part of the Atlantic equatorial mode (or the Atlantic Niño).

Further compared to rainfall anomalies [Figure 6], SST shows a quite different spatial Figure 6 pattern of variances as found in Figure 3. Large interannual-to-interdecadal SST variances Figure 3 appear mostly in the eastern part of the basin [e.g., Carton et al., 1996]. This rainfall-SST contrast configuration is much more evident than in the tropical Pacific [e.g., Wallace et al., 1998; Hoerling and Kumar, 2002], and may thus suggest a different relationship in the Atlantic between SST and rainfall on interannual and interdecadal time scales. A weaker equatorial mode in the Atlantic and its preferred summer season, unable to force enough strong in situ convection and rainfall anomalies as in the central and eastern equatorial Pacific, are probably two of the major reasons: 
16GU AND ADLER: INTERANNUAL RAINFALL VARIABILITY IN THE TROPICAL ATLANTIC REGION

\subsection{Seasonal Correlations between SST Indices}

Weak correlation between Nino3 and Atl3 has been shown in past studies [e.g., RuizBarradas et al., 2000; Wang, 2002]. There is also no clear evidence of the connection between Nino3 and TSA [e.g., Enfield and Mayer, 1997], while TNA has been shown to be related to ENSO [e.g., Curtis and and Hastenrath, 1995]. Regarding strong seasonal dependence [not shown; e.g., Chiang et al., 2002; Wang, 2002], we examine the impact of El Niño on the Atlantic modes (Atl3 and TNA-TSA) by means of estimating correlation coefficients at each individual month [Figure 12a, b], rather than computing the coefficients between the entire time series. Significant correlations between Nino3 and Atl3 can be found during April-June, suggesting the possible external modulation of the Atlantic equatorial mode during this season [e.g., Delecluse et al., 1994; Latif and Grötzner, 2000]. The interhemispheric mode is also impacted by anomalous activities in the tropical eastern Pacific, with a strong correlation with Nino3 during March-June. A strong lag-correlation between these two via PNA has already been shown in previous studies [e.g., Lanzante , 1996; Enfield and Mayer, 1997]. Contemporaneous correlation between Nino3 and $T N A-T S A$ tends to imply the ENSO events may also directly influence either component of $T N A-T S A$ via anomalous Walker circulation in addition to their remote modulation of $T N A$ through midlatitudes.

Within the tropical Atlantic, Atl3 and TNA-TSA are significantly correlated in January and during April-July [Figure 12c], roughly in agreement with past studies [e.g., Servain et al., 1999]. This relationship could be understood since Atl3 may actually represent part of the variability in the south tropical Atlantic [strong correlation can readily be found between $A t l 3$ and $T S A$ (not shown)], despite that the maximum variances
D R A F T
March 2, 2005, 10:13am
D R A F T 
GU AND ADLER: INTERANNUAL RAINFALL VARIABILITY IN THE TROPICAL ATLANTIC REGIONI7

of these two appear in different seasons, that is, during May-July and January-May, respectively (not shown).

\subsection{Correlations of SST Indices with Rainfall Anomalies and the ITCZ}

Contemporaneous linear correlations between the time series of rainfall and SST anomalies are calculated [Täble 1]. Both ENSO (Nino3) and the Atlantic equatorial mode (Atl3) show significant impacts on rainfall anomalies in the tropical Atlantic region, though the signs of their impact are always opposite. The warm (cold) events in the tropical centraleastern Pacific tend to suppress (enhance) rainfall in the Atlantic [e.g., Saravanan and Chang, 2000; Giannini et al., 2001b; Chiang et al., 2002]; in contrast, the warm (cold) phase of the Atlantic equatorial mode tends to enhance (decrease) rainfall in the basin. Furthermore, the Atlantic equatorial mode seems to influence the latitudes of the Atlantic ITCZ. Warmer (colder) SST in the deep tropics can move the ITCZ southward (northward). This mode can thus be one of the important factors modulating summer rainfall variability over West Africa [e.g., Janicot et al., 1998], particularly near the Gulf of Guinea. However, the correlation between Nino3 and Latitcz is not statistically significant, showing a much weaker simultaneous impact of ENSO, inasmuch as it could still influence the latitudes of the ITCZ via another means by modulating the tropical north Atlantic SST several months later [e.g., Curtis and and Hastenrath, 1995; Nobre and Shukla, 1996]. In addition, Atl3 and Nino3 are significantly, negatively correlated during April-June [Figure 12a], forming a much more complicated pattern.

Figure 12a

SST anomalies in either north or south tropical Atlantic are not significantly correlated to rainfall and ITCZ indices. However, their difference (TNA-TSA) representing the Atlantic interhemispheric mode shows a significant correlation with $L a t_{i t c z}$ suggesting 
18GU AND ADLER: INTERANNUAL RAINFALL VARIABILITY IN THE TROPICAL ATLANTIC REGION strong impact on the positions of the ITCZ. Anomalous latitudes of the ITCZ during boreal spring are closely related to anomälous rainfall patterns in northeast Brazil [e.g., Nobre and Shukla, 1996]. Nevertheless, TNA-TSA shows much weaker correlation with either $P_{d m}$ or $P_{i t c z}$, suggesting its limited direct forcing of rainfall anomalies in the tropical Atlantic.

Seasonal dependence of the relationship between SST modes and rainfall anomalies are further explored by computing correlation coefficients as a function of month [Figures 13 and 14]. Nino3 is strongly correlated with both $P_{i t c z}$ and $P_{d m}$ during JanuaryFebruary and April-July [Figures 13a]. Particularly, during April-July the correlation between Nino3 and $P_{d m}$ is consistently stronger than between Nino3 and $P_{i t c z}$, indicating a widespread modulation of rainfall in the tropical Atlantic by the tropical Pacific [e.g., Chiang et al., 2002]. Significant correlations are also observed between Nino3 and Lat $_{i t c z}$ during April-July [Figure 14a]. This seems to suggest seasonal modulations of the Figure 14a ITCZ locations by the ENSO events. However, we have to note that the intensity and position of the ITCZ themselves are strongly correlated with each other during this period [Figure 8]. It is thus possible that this ITCZ's self-correlation contributes a lot to seemingly direct modulation of $L a t_{i t c z}$ by Nino3. From Figure 13a, we can also find that in Figure 8 March the correlation between Nino3 and rainfall anomaly indices is weak as discovered before [e.g., Uvo et al., 1998; Chiang et al., 2002]. Neither $P_{i t c z}$ nor $P_{d m}$ is significantly correlated with Nino3 in this month.

Correlations between $A t l 3$ and $P_{d m}$ are consistently above the $5 \%$ confidence level during April-September [solid line in Figure 13b], showing a strong impact of the Atlantic equatorial mode on rainfall variability during this period in which the warmest SST anomalies 
GU AND ADLER: INTERANNUAL RAINFALL VARIABILITY IN THE TROPICAL ATLANTIC REGIONI 9 are usually observed in the equatorial region. Correlations of $P_{i t c z}$ with Atl3 are relatively weaker [dashed line in Figure 13b]; the correlation coefficient becomes statistically Figure 13b significant only in April and during July-August. Regarding Atl3 and Lat ${ }_{i t c z}$, significant correlations appear in several months: November-February and April-June [Figure 14b], implying anomalous latitudes of the ITCZ accompanying rainfall anomalies. Particularly during November-February, warm (cold) events can be seen in the equatorial Atlantic [Figure 9; Wang, 2002], while they seemingly can not effectively induce much rainfall anomalies [Figure 13b].

Figure 9

As indicated in Table 1, only weak correlations can be found between TNA-TSA and rainfall indices, i.e., $P_{i t c z}$ and $P_{d m}$ [Figure 13c]. Correlation coefficients above the $5 \%$ confidence level appear only in two months: April and October. However, consistent, significant correlations between $T N A-T S A$ and $L a t_{i t c z}$ are observed during boreal spring and early summer with only one exception: March [Figure $14 \mathrm{c}]$. The results enhance the argument that during boreal spring the Atlantic interhemispheric mode could effectively impact the latitudes of the ITCZ but have much less influence on the magnitude of rainfall anomalies in the tropical Atlantic.

\subsection{Composites}

To further quantify large-scale rainfall and sea surface anomalies, composite anomaly patterns are constructed on the basis of the extreme (warm) events deduced from Nino3 and Atl3. The interhemispheric mode $(T N A-T S A)$ will not be discussed here for its associated anomaly composite maps have been given and thoroughly discussed in Chiang et al. [2002]. Anomalous surface winds are derived using zonal and meridional $1000 \mathrm{mb}$ wind components from the NCAR/NCEP Reanalysis project [Kalnay et al., 1996]: 
20GU AND ADLER: INTERANNUAL RAINFALL VARIABILITY IN THE TROPICAL ATLANTIC REGION

\subsubsection{Pacific El Niño.}

During 1982-2003, five warm events are observed in the tropical eastern Pacific [solid line in Figure 9a]: 1982/1983, 1986/1987, 1991/1992, 1997/1998, and 2002/2003. Since warm SST quickly disappeared during the spring of 2003 , the composite only includes other four events, same as in Chiang et al. [2002]. Regarding the peak months of El Nño and seasonal dependence of variations in the tropical Atlantic, the composite maps of rainfall, SST, and surface wind anomalies are calculated for January-June of the next years, that is, 1983, 1987, 1992, and 1998.

The composite maps are generally similar as in Chiang et al. [2002]. However, monthly evolution patterns rather than two-month averages are given here, which are expected to provide more detail. Intense negative rainfall anomalies appear in January, covering much of northeast South America and extending across the tropical Atlantic [Figure 15]. Negative rainfall anomalies weaken in February, and reach the weakest in March, but become strong again in April and May. Also, in April and May, positive values appear north of the equator, forming a dipole feature in the west basin. Chiang et al. [2002] mentioned this feature and proposed that it may be due to the anomalous northward movement of the ITCZ during this season. A positive rainfall peak can even be seen around $22^{\circ} \mathrm{N}, 60^{\circ} \mathrm{W}$ as discovered in Saravanan and Chang [2000] and Chiang et al. [2002]. Concomitantly another positive peak appears south of the equator about $26^{\circ} S$, $52^{\circ} \mathrm{W}$, roughly the location of the South Atlantic convergence zone (SACZ) [e.g., Barreiro et al., 2002], suggesting the impact of El Nños [e.g., Trenberth et al., 1998].

Different from rainfall anomalies, very weak surface wind anomalies occur in the equatorial region in January, and strong wind anomalies tend to stay away from the equator. 
GU AND ADLER: INTERANNUAL RAINFALL VARIABILITY IN THE TROPICAL ATLANTIC REGION21

Cross-equatorial (southeasterly) wind anomalies become strong from February, first appearing in the western Atlantic and extending to the eastern basin. Most intense southeasterly anomalies occur in April and May.

North of the equator, since January SST becomes warmer near the West African coast and gradually encroaches the central-western part of the basin. Warmest SST is observed in March, though the warmer region continuously extends to the west in April and May. SST anomalies there attain their peak in March, but become weaker thereafter. South of the equator, negative SST anomalies appear off the Angola and Namibia coasts around $20^{\circ} S$ from February. Anomalous warm and cold events in this region, similar to, but much weaker than the Pacific El Niño, have been documented [e.g., Florenchie et al., 2003; Florenchie et al., 2004]. Negative SST anomalies extend to the equatorial region in April. Until May most evident negative SST anomalies can only be observed along the equator; furthermore, a prominent dipolar structure of SST anomalies shows up across the tropical Atlantic since April. It is also noted that there is a one-or-two-month lag between SST anomalies along the equator and near the Angola and Namibia coasts. This lag may indicate a causal connection between the Atlantic Niño and Benguela Niño.

A detailed, coherent seasonal evolution pattern of various anomalies can thus be drawn from Figure 15. Warm SSTs in the eastern Pacific associated with El Niño peaking in boreal winter force strong negative rainfall anomalies in the tropical Atlantic and northeast South America via anomalous Walker circulation and tropospheric warming as claimed in past studies [e.g., Chiang et al., 2002; Chiang and Sobel, 2002]. This is clearly supported by the lack of evident equatorial surface wind anomalies in January. Chiang et al. [2002] carefully justified the Walker mechanism through their analyses. Remote modulations of 
2QGU AND ADLER: INTERANNUAL RAINFALL VARIABILITY IN THE TROPICAL ATLANTIC REGION SST in the north tropical Atlantic by El Niño can be observed following the tropical Pacific warming with a peak in March. It is thus possible that the evident decrease of (negative) rainfall anomalies from January to March is due to a competition of anomalous Walker cell and gradually warmed SST north of the equator. Consequently, warm SST takes control in the tropical north Atlantic, while direct impact of Pacific El Niño continues to be felt in the equatorial region, enhanced by the negative SST anomalies which begin to appear along the equator in April. In May a strong cross-equatorial SST grandient is built up pushing the ITCZ to the north. This evolution feature may also account for the weak correlation between SST (Nino3) and rainfall indices in March [e.g., Uvo et al., 1998], in that March turns out to be right in the middle of the transition originated from the Pacific.

\subsubsection{Atlantic Equatorial Mode.}

Atlantic Niño can effectively modulate regional large-scale atmospheric circulation cells and West African rainfall variability [e.g.; Wang, 2002; Janicot et al., 1998], though it is much weaker than its Pacific counterpart and may not be self-sustaining [e.g., Zebiak, 1993; Carton and Huang, 1994; Ruiz-Barradas et al., 2000]. During 1982-2003, nine warm events are observed based on $A t l 3 \geq+0.5^{\circ} \mathrm{C}$ in at least three consecutive months [dashed line in Figure 9a]. The peak months are September 1984, July 1987, June 1988, November 1993, June 1995, June 1996, January 1998, July 1999, and August 2003. Excluding 1993, the identified warm events are generally consistent with Wang [2002], though he applied a different threshold of $+0.7^{\circ} \mathrm{C}$. Since we intend to focus on boreal summer, the peak month composites are constructed only based on eight warm events [Figure 16]: 1984, 1987, 1988, 
GU AND ADLER: INTERANNUAL RAINFALL VARIABILITY IN THE TROPICAL ATLANTIC REGION23 1995, 1996, 1998, 1999, and 2003. That 1998 is included is because the consistent warming extended from winter to summer, though its peak month is January.

A band of positive rainfall anomalies appears across the equator and tends to be located in the east basin. Negtive rainfall anomalies, though weak, are found north of it and near the coast of West Africa. Accompanying rainfall anomalies, cross-equatorial northwesterly to equatorial westerly wind anomalies are observed with a large area of warm SST occupying the eastern equatorial region just south of West African continent. This coherent spatial pattern is consistent with other studies and indicates a relatively strong dynamic coupling during Atlantic Niños [e.g., Ruiz-Barradas et al., 2000], as proposed in past studies [e.g., Zebiak, 1993].

Further detailed examinations of anomalous fields, however, show distinct seasonal evolution patterns for these individual warm events (not shown), implying that Atlantic Niño can beinduced by different mechanisms. One or two months before the peak warm month, rainfall and surface wind anomaly features can be totally different. An evident:example is illustrated in Figure 17. In June 1987 (one month before the peak month), evident negative rainfall anomalies occurred over the tropical Atlantic basin, in contrast to intense positive rainfall anomalies in May 1988, reflecting distinct situations in the equatorial $\mathrm{Pa}-$ cific [anomalous warm (cold) in 1987 (1988)] and opposite response in the tropical Atlantic during boreal spring. Though relatively weaak, anomalous warm SSTs in the tropical east Atlantic appeared in the following months in both years. It thus seems that the tropical Atlantic has similar response during boreal summer to the two distinctly different remote forcings. Further examination of seasonal evolution patterns in 1987 indicated part of the equatorial warmer water came from the north Atlantic which was probably excited by the 
24GU AND ADLER: INTERANNUAL RAINFALL VARIABILITY IN THE TROPICAL ATLANTIC REGION

Pacific during boreal spring [e.g., Curtis and Hastenrath, 1995]. It is therefore misleading to construct composite maps of seasonal evolution for all Atlantic Niño events. To explore the origins and mechanisms of Atlantic Niño, detailed case studies are necessary.

Past studies argued that Atlantic Niño might be connected to the tropical Pacific through intense modulations of ENSO on the tropical Atlantic basin during boreal spring [e.g., Delecluse et al., 1994; Latif and Grötzner, 2000]. Equatorial SST anomalies along the equator become strong only after May, and may thus be a time-lag remote, oceanic response to the rainfall and surface wind anomalies in the western portion of the basin [e.g., Zebiak, 1993; Florenchie et al., 2004]. From 1982 to 2003, all four cold events (in $1982,1983,1992$, and 1997) occuring in the equatorial Atlantic follow the anomalous warm events in the Pacific; except for 1985, the other three evident La Niñas in the Pacific are followed by Atlantic Niños. This might be the reason for high correlations between Nino3 and Atl3 during early summer [Figure 12a]. Also, it seems to suggest a close relationship between the Atlantic Niño and Benguela Niño (not shown). In some years, for instance 1988, SST anomalies near the Angola and Namibia coasts often appear one or two months before those along the equator.

\section{Summary and Concluding Remarks}

Rainfall variability on seasonal and interannual-to-interdecadal time scales in the tropical Atlantic is quantified using the 25-year GPCP product. Evident seasonal variations exist in the basin-mean rainfall, and the marine ITCZ and its latitudes. More (less) basin-mean rainfall and a stronger (weaker) ITCZ are observed when it moves to the north (south) during boreal summer and fall (winter and spring). However, most intense variations of rainfall on interannual-to-interdecadal time scales occur during boreal spring, 
showing a different seasonal preference. Also, the interannual-to-interdecadal variances of rainfall tend to be located in the western part of the basin. Particularly, over open ocean the variances within the period bands of $1-2$ and $6-12$ years tend to avoid the region of $0-2.5^{\circ} \mathrm{N}$, while those with a period of $2-6$ years are roughly concentrated in this region.

The impacts of three major (local and remote) SST modes are discussed in this study. SST indices representing the Atlantic Niño (Atl3) and interhemispheric (TNA-TSA) modes have similar wavelet spectral peaks as rainfall anomalies, whereas the ENSO in$\operatorname{dex}($ Nino3) only shows one single power peak within the period range of around $2-6$ years. As rainfall variances, SST variances within the period bands of $1-2$ and $6-12$ years are located off the region just north of the equator, and those with a period of $2-6$ years tend to be along the equator. Nevertheless, major SST variances on the interannual-to-interdecadal time scales prefer the eastern portion of the basin, in contrast to the preference of rainfall variances. This contrast structure probably indicates a unique relationship between rainfall and SST on the interannual-to-interdecadal time scales.

Correlation analyses indicate that rainfall anomalies including the basin-mean rainfall and the ITCZ intensity are strongly modulated by the SST anomalies in both the Pacific (Nino3) and the equatorial Atlantic (Atl3). El Niños influence the tropical Atlantic through two distinct means [e.g., Saravanan and Chang, 2000; Giannini et al., 2001b; Chiang et al., 2002]: (1) suppress rainfall over the tropical Atlantic basin via anomalous Walker circulation and increased stability through tropospheric warming, and (2) contribute to the formation of the positive-negative dipole in rainfall anomalies through their modulations of SST in the tropical north Atlantic and perhaps in the equatorial and 
26GU AND ADLER: INTERANNUAL RAINFALL VARIABILITY IN THE TROPICAL ATLANTIC REGION tropical south Atlantic several months later. Composite maps further detail the evolutions of anomalous patterns based on the four strong warm events in the eastern Pacific during 1982-2003. The time-lag between these two influences is clearly shown, as are the opposite, self-competing impacts of El Niños in the tropical Atlantic. It is thus likely that because of these opposite impacts, strong negative rainfall anomalies covering the entire tropical Atlantic basin in January gradually evolove into a positive-negative dipole in rainfall anomalies in May. This may also explain why the correlation between rainfall anomalies and Nino3 is so weak in March [Figures 13 and 14; Uvo et al., 1998], likely implying the two opposite effects reach their peaks and tend to cancel each other.

Regarding Atlantic Niño, both rainfall and latitudes of the ITCZ are directly impacted, though it appears that the Atlantic equatorial warming itself might be externally forced [e.g., Delecluse et al., 1994; Latif and Grötzner, 2000]. The warm events usually occur during boreal summer or late spring. A composite analysis indicates a coupled, coher-. ent spatial pattern during the peak months [e.g., Zebiak, 1993]: On the other hand, the Atlantic interhemispheric mode can effectively impact the locations of the ITCZ, particularly during boreal spring and early summer, but has little influence on the magnitudes of rainfall anomalies. This mode may also be significantly modified by the Pacific El Niño [Figure 15].

Figure 15

This study provides an observational quantification of rainfall variability in the tropical Atlantic. The relationships between rainfall anomalies and (local and remote) SST forcings are also investigated. However, detailed mechanisms about these relationships are still not quite clear and straightforward possibly due to the existence of several competing forcing modes in the basin. Further explorations of air-sea coupling processes in the tropical 
GU AND ADLER: INTERANNUAL RAINFALL VARIABILITY IN THE TROPICAL ATLANTIC REGIONR7 Atlantic and external or remote influences may be done in the future with the help of well-designed, more realistic coupled models on the basis of past results [e.g., Chang et al., 2000; Saravanan and Chang, 2000], and also with the availability of more high-quality in situ and satellite observations. Thus, several related issues have not been addressed here. (1) Anomalous warm SSTs occur in the tropical north Atlantic several months after the peaks of El Niños in the Pacific [Figure 15]. How these warm SSTs impact rainfall patterns is still a puzzle since most intense rainfall anomalies tend to be in the western portion of the basin. (2) El Niños may also have impact on the SSTs along and south of the equator through an indirect way. Anomalous cold SST is observed in both the Benguela Niño and Atlantic Niño regions one or two months after most intense rainfall and cross-equatorial wind anomalies in the western portion of the tropical Atlantic [Figures 15 and 17]. This seems to be in contrast with past results [e.g., Enfield and Mayer, 1997] and has yet to be further examined. (3) What mechanisms control the Atlantic equatorial anomalies during boreal summer and fall is still a question. Although the opposite (warm/cold) phases of the Pacific may excite similar response in the equatorial Atlantic [Figure 16], Figure 16 in most cases anomalously strong rainfall anomalies occur in April prior to the equatorial warming, and high lag-correlation between surface wind anomalies in the west basin and SST anomalies in the east basin can always be found. (4) There seems a link between the equatorial Atlantic and Benguela Niños since in general the anomalies in the region off the Angola and Namibia coasts occur earlier than the equatorial anomalies. Florenchie et al. [2004] showed that Benguela Niño usually peaks in March/April, compared with the peak season (boreal summer) of the equatorial warming. It has also been suggested that subsurface temperature anomalies forced by surface wind anomalies in the west- 
28GU AND ADLER: INTERANNUAL RAINFALL VARIABILITY IN THE TROPICAL ATLANTIC REGION central equatorial Atlantic propagate eastward but outcrop only at regions off the Angola and Namibia coasts [e.g., Florenchie et al., 2003; Florenchie et al., 2004]. However, the conclusions can be made only after further quantifying related oceanic components, particularly the variability in the subsurface ocean. (5) Intense atmospheric (rainfall and surface winds) responses to the equatorial Pacific during boreal spring are evident in the western portion of the basin including the northeast coastal region of South America [Figure 15], suggesting a relatively easier communication can be built between remote forcing and the surface through moist convection within the ITCZ [Chiang and Sobel, 2002]. Further examinations of the Atlantic Niño events indicate (not shown), even in the quiet years of Pacific, strong rainfall and surface wind anomalies in the west equatorial region can be found one or two months before the equatorial warming. Land surface processes and associated convection may thus be one of the major reasons and their relationships with oceanic components have to be quantified in the future. Finally, we have not discussed the possible impact of NAO on the tropical Atlantic. Several past studies showed that the NAO may induce large-scale circulation anomalies and impact Carribbean rainfall through its modulation of SST in the tropical region [e.g., Wang, 2002; Giannini et al., 2001a].

Acknowledgments. The authors thank Dr. Chidong Zhang for commenting on an early version. Mr. David Bolvin prepared the GPCP rainfall data. NCAR/NCEP Reanalysis data were provided by the NOAA-CIRES Climate Diagnostics Center, Boulder, Colorado, USA, from its Web site at http://www.cdc.noaa.gov. This work is supported through the TRMM Science Team under the NASA Headquarters TRMM Program Scientist Dr. Ramesh Kakar. 
GU AND ADLER: INTERANNUAL RAINFALL VARIABILITY IN THE TROPICAL ATLANTIC REGION29

\section{References}

Adler, R. F., and Co-authors, The version 2 Global Precipitation Climatology Project (GPCP) monthly precipitation analysis (1979-present), J. Hydrometeor., 4, 1147-1167, 2003.

Andreoli, R. V., and M. T. Kayano, Multi-scale variability of the sea surface temperature in the Tropical Atlantic, J. Geophys. Res., 109, C05009, doi:10.1029/2003JC002220, 2004.

Barreiro, M., P. Chang, and R. Saravanan, Variability of the South Atlantic convergence zone simulated by an atmospheric general circulation model, J. Climate, 15, 745-763, 2002.

Carton, J. A., X. Cao, B. S. Giese, and A. M. da Silva, Decadal and interannual 'SST variability in the tropical Atlantic ocean, J. Phys. Oceanogr., 26, 1165-1175, 1996.

Carton, J. A., and B. Huang, Warm events in the tropical Atlantic, J. Phys. Oceanogr., 24, 888-903, 1994.

Chang, P., R. Saravanan, L. Ji, and G. C. Hegerl, The effect of local sea surface temperature on atmospheric circulation over the tropical Atlantic sector, J. Climate, 13, $2195-2216,2000$.

Chiang, J. C. H., Y. Kushnir, and S. E. Zebiak, Interdecadal changes in eastern Pacific ITCZ variability and its influence on the Atlantic ITCZ, Geophys. Res. Lett., 27, 3687$3690,2000$.

Chiang, J. C. H., Y. Kushnir, and A. Giannini, Reconstructing Atlantic Intertropical Convergence Zone variability: Influence of the local cross-equatorial sea surface temperature gradient and remote forcing from the eastern equatorial Pacific, J. Geophys. 
30GU AND ADLER: INTERANNUAL RAINFALL VARIABILITY IN THE TROPICAL ATLANTIC REGION Res., 107(D1), 4004, doi:10.1029/2000JD000307, 2002.

Chiang, J. C. H., and A. H. Sobel, Tropical tropospheric temperature variations caused by ENSO and their influence on the remote tropical climate, J. Climate, 15, 2616-2631, 2002 .

Curtis, S., and S. Hastenrath,Forcing of anomalous sea surface temperature evolution in the tropical Atlantic during Pacific warm events, J. Geophys. Res., 100, 15835-15847, 1995.

Delecluse, P., J. Servain, C. Levy, K. Arpe, and L. Bengtsson, On the connection between the 1984 Atlantic warm event and the 1982-1983 ENSO, Tellus, 46A, 448-464, 1994.

Enfield, D. B., and D. A. Mayer, Tropical Atlantic sea surface temperature variability and its relation to El Niño-Southern Oscillation, J. Geophys. Res., 102C1, 929-945, 1997.

Enfield, D. B., A. M. Mestas-Nunez, D. A. Mayer, and L. Cid-Serrano, How ubiquitous is the dipole relationship in tropical Atlantic sea surface temperature? J. Geophys, Res., 104, 7841-7848, 1999.

Florenchie, P., J. R. E. Lutjeharms, C. J. C. Reason, S. Masson, and M. Rouault, The source of Benguela Niños in the South Atlantic Ocean, Geophys. Res. Lett., 30, 1505, doi:10.1029/2003GL017172, 2003.

Florenchie, P., C. J. C. Reason, J. R. E. Lutjeharms, M. Rouault, C. Roy, and S. Masson, Evolution of interannual warm and cold events in the Southeast Atlantic Ocean, $J$. Climate, 17, 2318-2334, 2004.

Giannini, A., M. A. Cane, and Y. Kushnir, Interdecadal changes in the ENSO teleconnection to the Caribbean region and the North Atlantic Oscillation, J. Climate, 14 , 2867-2879, 2001a. 
GU AND ADLER: INTERANNUAL RAINFALL VARIABILITY IN THE TROPICAL ATLANTIC REGIONB1

Giannini, A., J. C. H. Chiang, M. A. Cane, Y. Kushnir, and R. Seager, The ENSO teleconnection to the tropical Atlantic ocean: Contributions of the remote and local SSTs to rainfall variability in the tropical Americas, J. Climate, 14, 4530-4544, 2001b.

Grist, J. P., and S. E. Nicholson, A study of the dynamic factors influencing the rainfall variability in the west African Sahel, J. Climate, 14, 1337-1359, 2001.

Grodsky, S. A., and J. A. Carton, The intertropical convergence zone in the South Atlantic and the equatorial cold tongue, J. Climate, 16, 723-733, 2003.

Gu, G., R. F. Adler, G. J. Huffman, and S. Curtis, Summer synoptic-scale waves over West Africa observed by TRMM, Geophys. Res. Lett., 30, 1729, doi:10.1029/2003GL017402, 2003.

Gu, G., and R. F. Adler, Seasonal evolution and variability associated with the West African monsoon system, J. Climate, 17, 3364-3377, 2004.

Hastenrath, S., and L. Greischar, Circulation mechanisms related to northeast Brazil. rainfall anomalies, J. Geophys. Res., 98, 5093--5102, 1993.

Hoerling, M. P., and A. Kumar, Atmospheric response patterns associated with tropical forcing, J. Climate, 15, 2184-2203, 2002.

Houghton, R. W., and Y. Tourre, Characteristics of low-frequency sea surface temperature fluctuations in the tropical Atlantic, J. Climate, 5, 765-771, 1992.

Janicot, S., A. Harzallah, B. Fontaine, and V. Moron, West African Monsoon dynamics and eastern equatorial Atlantic and Pacific SST anomalies (1970-88), J. Climate, 11, 1874-1882, 1998.

Kalnay, E., and Co-authors, The NCEP/NCAR 40-year reanalysis project, Bull. Am. Meteorol. Soc., 77, 437-471, 1996. 
32GU AND ADLER: INTERANNUAL RAINFALL VARIABILITY IN THE TROPICAL ATLANTIC REGION

Landsea, C. W., R. A. Pielke, Jr., A. M. Mestas-Nuñez, and J. A. Knaff, Atlantic basin hurricanes: Indices of climatic changes, Climate Change, 42, 89-129, 1999.

Lanzante, J. R., Lag relationships involving tropical sea surface temperature, J. Climate, 9, 2568-2578, 1996.

Latif, M., and A. Grötzner, The equatorial Atlantic oscillation and its response to ENSO, Climate Dyn., 16, 213-218, 2000.

Liu, W. T., and X. Xie, Double intertropical convergence zone-a new look using scatterometer. Geophys. Res. Lett., 29, 222072, doi:10.1029/2002GL015431, 2002.

Nobre, P., and J. Shukla, Variations of sea surface temperature, wind stress, and rainfall over the tropical Atlantic and South America, J. Climate, 9, 2464-2479, 1996.

Rasmusson, E. M., and T. H. Carpenter, Variations in tropical sea surface temperature and surface wind fields associated with the Southern Oscillation/El Niño, Mon. Weather -Rev., 110, 354-384, 1982.

Reynolds, R. W., and T. M. Smith; Improved global sea surface temperature analyses using optimum interpolation, J. Climate, 7, 929-948, 1994.

Ruiz-Barradas, A., J. A. Carton, and S. Nigam, Structure of interannual-to-decadal climate variability in the tropical Atlantic sector, J. Climate, 13, 3285-3297, 2000.

Saravanan, R., and P. Chang, Interaction between tropical Atlantic variability and El Niño-Southern oscillation, J. Climate, 13, 2177-2194, 2000.

Servain, J., J. Picaut, and J. Merle, Evidence of remote forcing in the equatorial Atlantic ocean, J. Phys. Oceanogr., 12, 457-463, 1982.

Servain, J., I. Wainer, J. P. McCreary Jr., and A. Dessier, Relationship between the equatorial and meridional modes of climate variability in the tropical Atlantic, Geophys. 
GU AND ADLER: INTERANNUAL RAINFALL VARIABILITY IN THE TROPICAL ATLANTIC REGION33 Res. Lett., 26, 485-488, 1999.

Sutton, R. T., S. P. Jewson, and D. P. Rowell, The elements of climate variability in the tropical Atlantic region, J. Climate, 13, 3261-3284, 2000.

Thorncroft, C. D., and D. P. Rowell, Interannual variability of African wave activity in a general circulation model, Int. J. Climatol., 18, 1306-1323, 1998.

Torrence C., and G. P. Compo, 1998: A practical guide to wavelet analysis. Bull. Am. Meteorol. Soc., 79, 61-78, 1998.

Tourre, Y. M., B. Rajagopalan, and Y. Kushnir, Dominant patterns of climate variability in the Atlantic Ocean during the last 136 years, J. Climate, 12, 2285-2299, 1999.

Trenberth, K. E., G. W. Branstator, D. Karoly, A. Kumar, N.-C. Lau, and C. Ropelewski, Progress during TOGA in understanding and modeling global teleconnections associated with tropical sea surface temperatures, J: Geophys. Res., 103, 14291-14324, 1998.

Uvo, C. B., C. A. Repelli, S. E. Zebiak, and Y. Kushnir, The relationship between tropical Pacific and Atlantic SST and northeast Brazil monthly precipitation, J. Climate, 11, $551-562,1998$.

Wagner, R. G., Decadal-scale trends in mechanisms controlling meridional sea surface temperature gradients in the tropical Atlantic, J. Geophys. Res., 101, 16683-16694, 1996.

Wainer, I., and J. Soares, North northeast Brazil rainfall and its decadal-scale relationship to wind stress and sea surface temperature, Geophys. Res. Lett., 24, 277-280, 1997.

Wallace, J. M., E. M. Rasmusson, T. P. Mitchell, V. E. Kousky, E. S. Sarachik, and H. von Storch, On the structure and evolution of ENSO-related climate variability in the tropical Pacific: Lesson from TOGA, J. Geophys. Res., 103(C7), 14241-14259, 1998 
34 GU AND ADLER: INTERANNUAL RAINFALL VARIABILITY IN THE TROPICAL ATLANTIC REGION

Wang, C., Atlantic climate variability and its associated atmospheric circulation cells, $J$. Climate, 15, 1516-1536, 2002.

Xie, S.-P., and Y. Tanimoto, A Pan-Atlantic decadal climate oscillation, Geophys. Res. Lett., 25, 2185-2188, 1998.

Zebiak, S. E., Air-sea interaction in the equatorial Atlantic region, J. Climate, 6, 1567$1586,1993$. 
Figure 1. Seasonal mean precipitation $\left(m m d a y^{-1}\right)$ and $\operatorname{SST}\left({ }^{\circ} C\right)$ in the tropical Atlantic region.

Figure 2. Seasonal mean precipitation in the center of the Atlantic ITCZ ( $\mathrm{mm}$ $d a y^{-1} ;$ solid line) and averaged over $17.5^{\circ} \mathrm{S}-22.5^{\circ} \mathrm{N}, 15^{\circ} \mathrm{W}-37.5^{\circ} \mathrm{W}(0.3 \times \mathrm{mm}$ $d a y^{-1}$; dashed line), and seasonal mean latitudes of the center of the Atlantic ITCZ $\left({ }^{\circ} N\right.$; dashdot line).

Figure 3. Seasonal mean variances of precipitation $\left(m m^{2} d a y^{-2}\right)$ and SST $\left(\left({ }^{\circ} C\right)^{2}\right)$ in the tropical Atlantic region. 
Figure 4. (a) Precipitation anomalies $\left(\mathrm{mm} \mathrm{day}^{-1}\right)$ in the center of the Atlantic $\operatorname{ITCZ}\left(P_{i t c z} ;\right.$ solid line), and over $17.5^{\circ} S-22.5^{\circ} \mathrm{N}, 15^{\circ}-37.5^{\circ} \mathrm{W}$ ( $P_{d m} ;$ dashed line); (b) Anomalies (degree) of the central latitudes of the Atlantic ITCZ. The Atlantic ITCZ is defined between $15^{\circ} \mathrm{W}-37.5^{\circ} \mathrm{W}$. Shown here are three-month running averages.

Figure 5. Mean wavelet spectral power of the precipitation anomalies in the center of the Atlantic ITCZ (solid line); the latitudinal position anomalies of the center of the Atlantic ITCZ (dashed line), and the precipitation anomalies averaged over $17.5^{\circ} \mathrm{S}-22.5^{\circ} \mathrm{N}, 15^{\circ} \mathrm{W}-37.5^{\circ} \mathrm{W}$ (dashdot line). Also shown are the red noise spectra (dotted lines) for solid and dashed lines, respectively, computed from the lag-one autocorrelation. 
Figure 6. Variances of precipitation anomalies $\left(\mathrm{mm}^{2} d a y^{-2}\right)$ in the tropical Atlantic within various period ranges: (a) $1-2$ years, (b) $2-6$ years, and (c) $6-12$ years.

Figure 7. (a) Variance of the precipitation anomalies averaged over $17.5^{\circ} \mathrm{S}-$ $22.5^{\circ} \mathrm{N}, 15^{\circ}-37.5^{\circ} \mathrm{W}$, (b) variance of the precipitation anomalies in the center of the Atlantic ITCZ, and (c) the latitudinal anomalies of the Atlantic ITCZ as a function of month.

Figure 8. Linear correlation between the precipitation anomalies averaged over $17.5^{\circ} \mathrm{S}-22.5^{\circ} \mathrm{N}, 15^{\circ}-37.5^{\circ} \mathrm{W}\left[P_{d m}\left(\mathrm{~mm} \mathrm{day}^{-1}\right)\right.$; solid line $]$ and in the center of the Atlantic ITCZ $\left[P_{i t c z}\left(m m d a y^{-1}\right)\right.$; dashed line], and the Atlantic ITCZ's latitudinal anomalies $\left(L a t_{i t c z}\right) \cdot \gamma= \pm 0: 4$ denotes the $5 \%$ confidence level based on 23 degrees of freedom $($ dof $)$. 
Figure 9. (a) The SST anomalies $\left({ }^{\circ} \mathrm{C}\right)$ represent the eastern Pacific Niño3 mode (Nino3; solid line) and the Atlantic equatorial mode (Atl3; dashed line); (b) the SST anomaly difference $\left({ }^{\circ} \mathrm{C}\right)$ between the tropical north and south Atlantic oceans ( $T N A-T S A)$ represents the interhemispheric gradient mode. Three-month running average is applied.

Figure 10. Mean wavelet spectral power of (a) the Atlantic equatoriai mode (Atl3; solid line; dashdot line is the red spectrum) and the Atlantic gradient mode (TNA - TSA; dashed line; dotted line is the red spectrum), and (b) the Niño 3.SST anomalies (Nino3; solid line; dashed line is the red spectrum). The cross line in (a) denotes the mean spectral power of SST anomalies over $20^{\circ} \mathrm{S}-20^{\circ} \mathrm{N}$, $16^{\circ} \mathrm{W}-38^{\circ} \mathrm{W}$

Figure 11. Variances of SST anomalies in the tropical Atlantic within various period ranges: (a) $1-2$ years, (b) $2-6$ years, and (c) 6-12 years. 
Figure 12. Linear correlation between (a) Nino3 and Atl3, (b) Nino3 and $T N A-T S A$, and (c) Atl3 and TNA-TSA. Dashdot lines denote the $5 \%$ confidence level based on 20 degree of freedom (dof).

Figure 13. Linear correlation between the precipitation anomalies averaged over $17.5^{\circ} \mathrm{S}-22.5^{\circ} \mathrm{N}, 15^{\circ} \mathrm{W}-37.5^{\circ} \mathrm{W}\left[P_{d m}\left(\mathrm{~mm} d a y^{-1}\right)\right.$; solid lines $]$ and in the center of the Atlantic ITCZ $\left[P_{i t c z}\left(m m d a y^{-1}\right)\right.$; dashed lines], and the SST anomalies $\left({ }^{\circ} \mathrm{C}\right)$ representing (a) the eastern Pacific Niño 3 mode (Nino3), and the Atlantic equatorial modes: (b) Atl3 and (c) TNA-TSA. $\gamma= \pm 0.42$ denotes the $5 \%$ confidence level based on 20 degree of freedom (dof). 
Figure 14. Linear correlation between the latitudinal anomalies of the center of the Atlantic ITCZ $\left(L a t_{i t c z}\right)$, and the SST anomalies representing (a) the eastern Pacific Niño 3 mode (Nino3), (b) the Atlantic equatorial mode (Atl3) and (c) the Atlantic gradient mode $(T N A-T S A)$. Dashed lines denote the $5 \%$ confidence level based on 20 degree of freedom (dof).

Figure 15. Anomaly composite maps corresponding to the eastern Pacific equatorial mode during January-May (1983, 1987, 1992, and 1998). Left panel is for precipitation anomalies (contour interval $1 \mathrm{~mm} \mathrm{day}^{-1}$ ); Right panel for SST (contour interval $0.3{ }^{\circ} \mathrm{C}$ ) and $1000 \mathrm{mb}$ wind vector $\left(\mathrm{m} \mathrm{s}^{-1}\right)$ anomalies. Positive (negative) anomalies are solid (dashed). The unit of winds is $m s^{-1}$. 
Figure 16. Anomaly composite maps corresponding to the warmest months in the eastern Atlantic (1984, 1987, 1988, 1995, 1996, 1998, 1999, and 2003). Contour intervals are $1 \mathrm{~mm} d a y^{-1}$ for rainfall anomalies and $0.3^{\circ} \mathrm{C}$ for SST anomalies, respectively; Positive (negative) anomalies are solid (dashed). The unit of winds is $m s^{-1}$.

Figure 17. Anomaly maps in 1987 and 1988. The warmest months are July in 1987 and June in 1988. Contour intervals are $1.5 \mathrm{~mm} \mathrm{day}^{-1}$ for rainfall anomalies (a, c, e, and g) and $0.5^{\circ} \mathrm{C}$ for SST anomalies (b, d, f, and h), respectively; Positive (negative) anomalies are solid (dashed). The unit of winds is $\mathrm{m} \mathrm{s}^{-1}$. 
Table 1: Correlation coefficients $(\gamma)$ between the precipitation anomalies averaged over $17.5^{\circ} \mathrm{S}-22.5^{\circ} \mathrm{N}, 15^{\circ}-37.5^{\circ} \mathrm{W}\left[P_{d m}\left(m m d a y^{-1}\right)\right]$ and in the center of the Atlantic ITCZ $\left[P_{i t c z}\right.$ $\left.\left(m m d a y^{-1}\right)\right]$, the anomalies of the central latitudes of the Atlantic ITCZ [ $\left.\operatorname{Lat}_{i t c z}\left(^{\circ}\right)\right]$, and the time series of SST anomalies representing various tropical oscillation modes. $\gamma=0.42$ is the $5 \%$ confidence level based on 20 degree of freedom (dof).

\begin{tabular}{l|c|c|c|c|c}
\hline$\gamma$ & Niño 3 & Atl 3 & TNA - TSA & TNA & TSA \\
\hline \hline$P_{d m}$ & $\mathbf{- 0 . 5 3}$ & $\mathbf{0 . 5 4}$ & -0.34 & -0.05 & 0.38 \\
\hline$P_{i t c z}$ & $\mathbf{- 0 . 4 9}$ & $\mathbf{0 . 5 1}$ & -0.15 & 0.07 & 0.27 \\
\hline Lat $_{i t c z}$ & 0.3 & $\mathbf{- 0 . 4 7}$ & $\mathbf{0 . 5}$ & 0.26 & -0.41 \\
\hline \hline
\end{tabular}



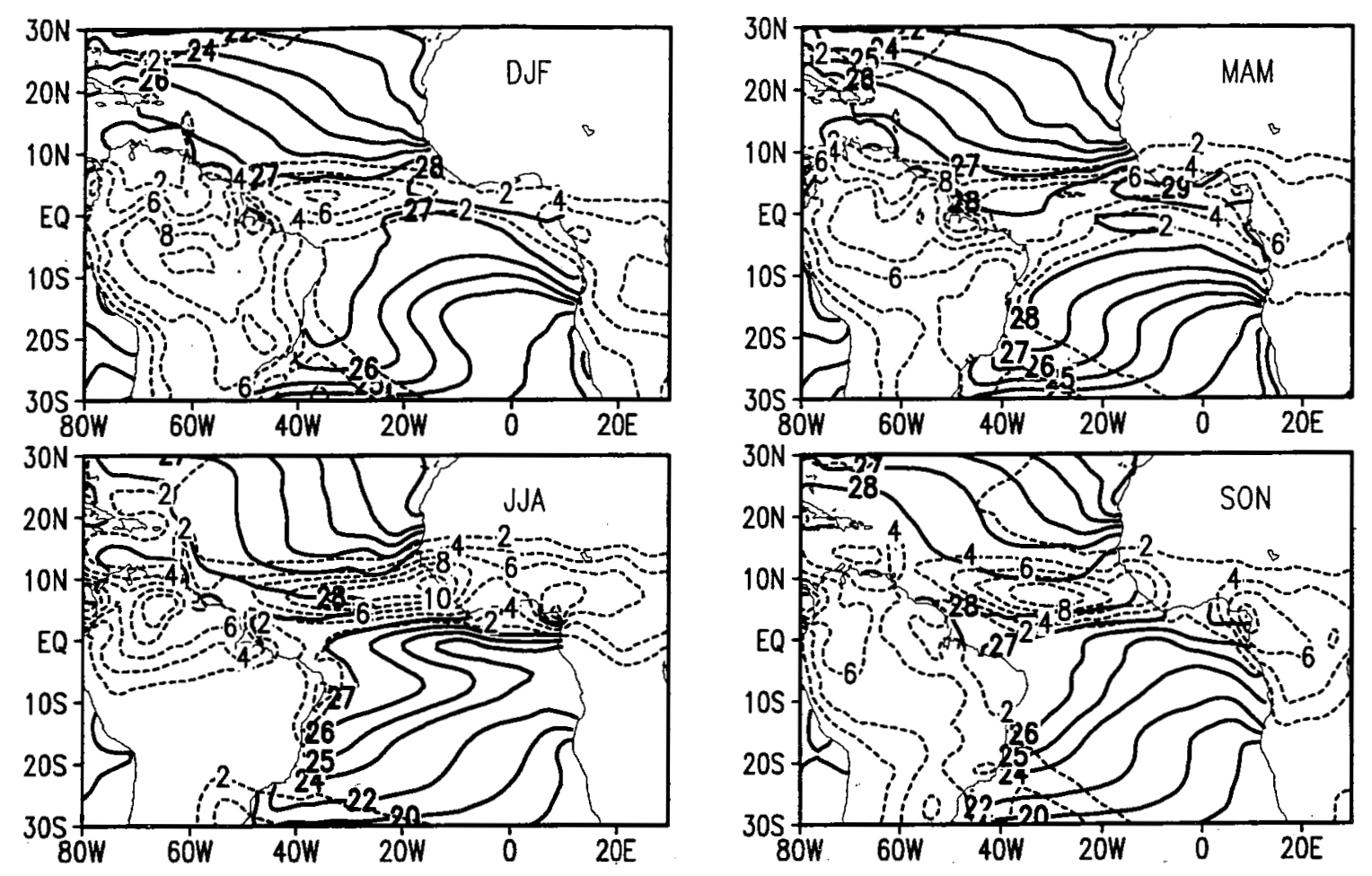

Figure 1: Seasonal mean precipitation ( $m m d a y^{-1}$; dashed contours) and $\operatorname{SST}\left({ }^{\circ} C\right.$; solid contours) in the tropical Atlantic region. DJF-December-February, MAM-March-May, JJA-June-August, and SON-September-November. 


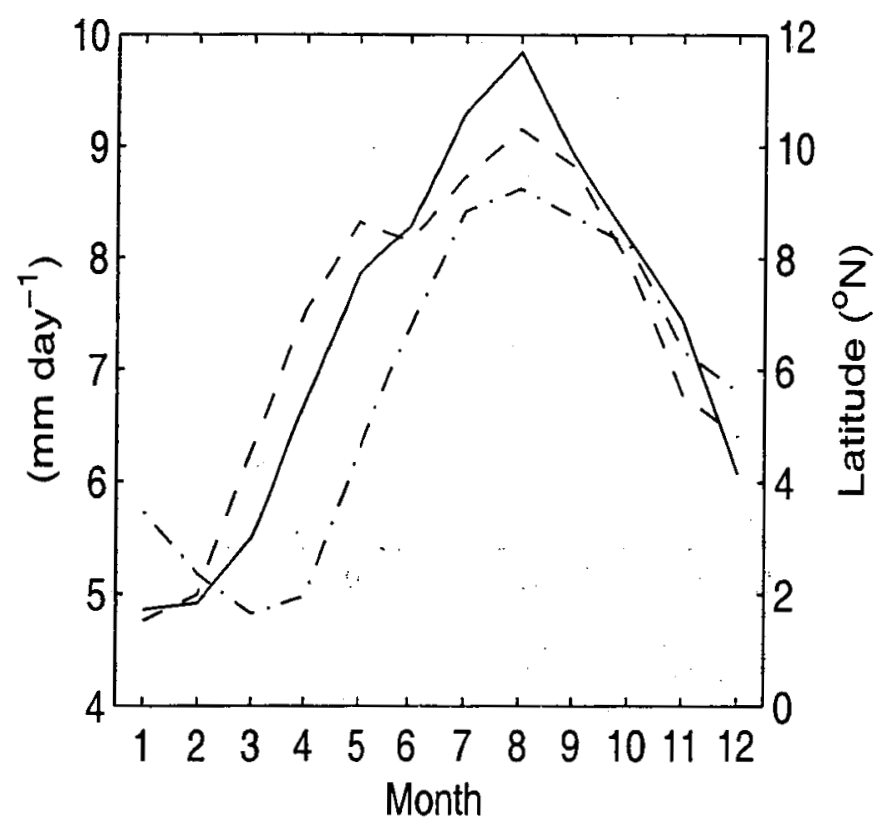

Figure 2: Seasonal mean precipitation in the center of the Atlantic ITCZ ( $m m d a y^{-1}$; solid line) and averaged over $17.5^{\circ} \mathrm{S}-22.5^{\circ} \mathrm{N}, 15^{\circ} \mathrm{W}-37.5^{\circ} \mathrm{W}\left(0.3 \times \mathrm{mm}\right.$ day ${ }^{-1}$; dashed line $)$, and seasonal mean latitudes of the center of the Atlantic ITCZ $\left({ }^{\circ} N\right.$; dashdot line). 

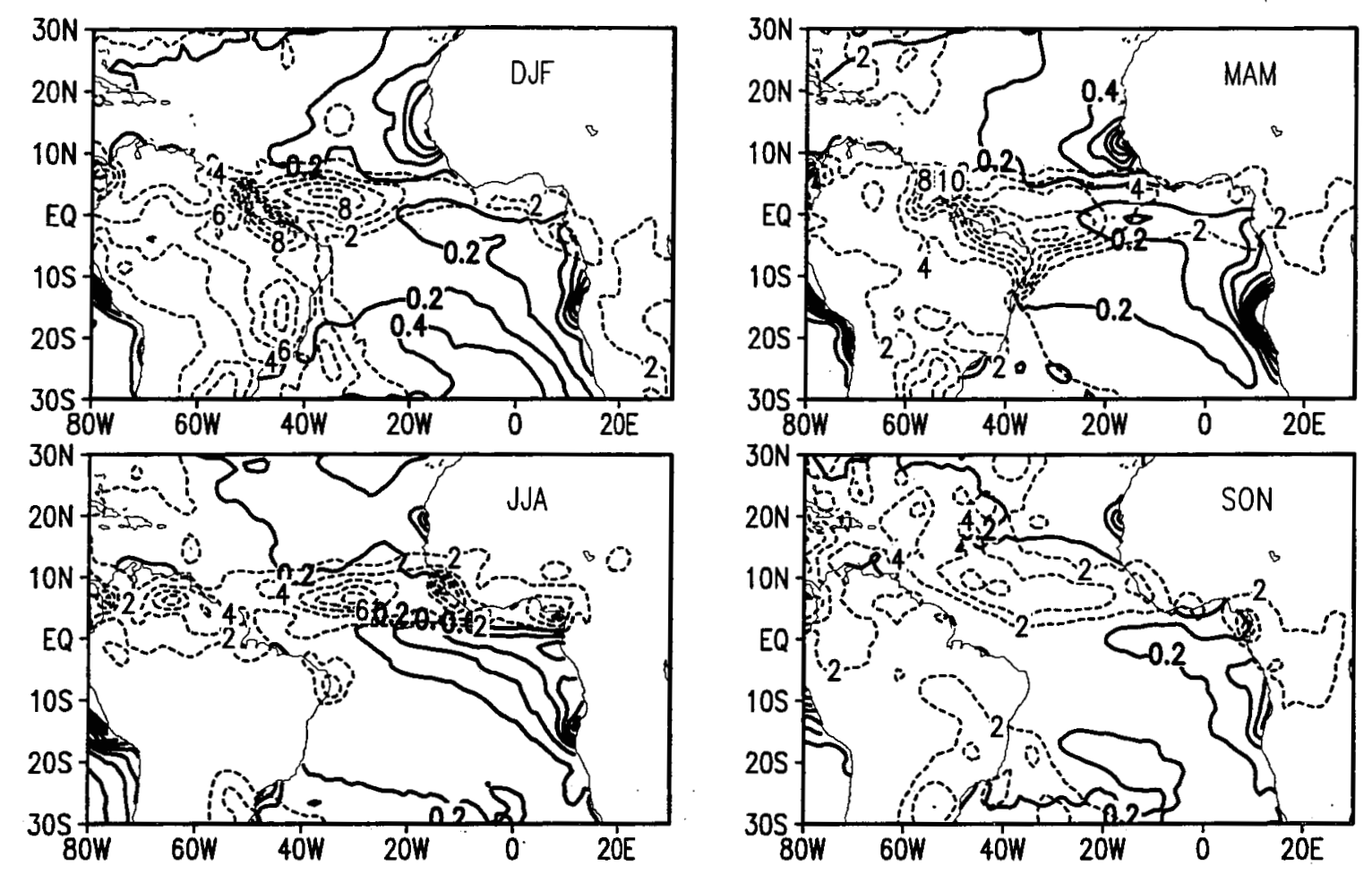

Figure 3: Seasonal mean variances of precipitation $\left(\mathrm{mm}^{2} d a y^{-2}\right.$; dashed contours) and SST $\left(\left({ }^{\circ} \mathrm{C}\right)^{2} ;\right.$ solid contours) in the tropical Atlantic region. 
(a) Precipitation anomalies

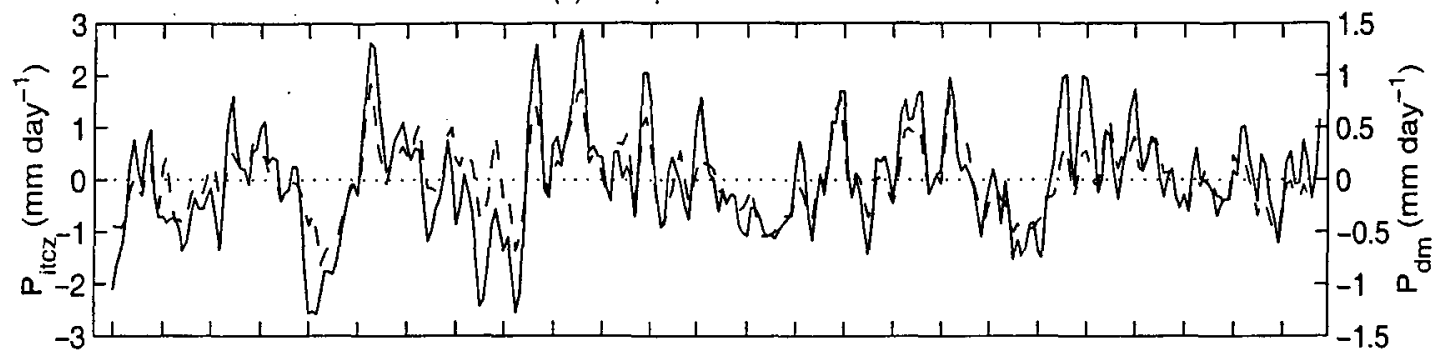

(b) ITCZ latitude anomalies

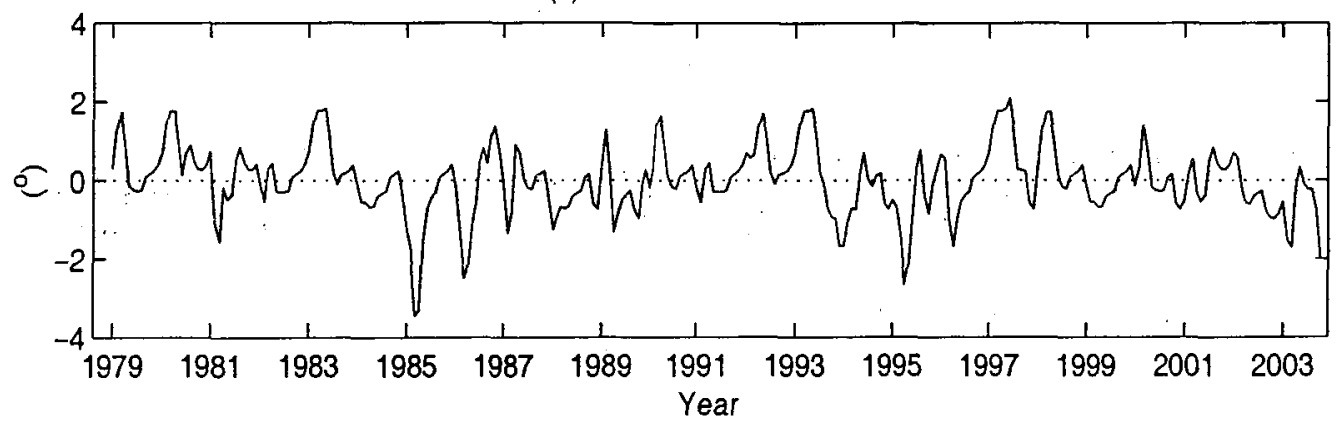

Figure 4: (a) Precipitation anomalies $\left(m m d a y^{-1}\right)$ in the center of the Atlantic ITCZ $\left(P_{i t c z}\right.$; solid line), and over $17.5^{\circ} S-22.5^{\circ} \mathrm{N}, 15^{\circ}-37.5^{\circ} \mathrm{W}\left(P_{d m}\right.$; dashed line); (b) Anomalies (degree) of the central latitudes of the Atlantic ITCZ. The Atlantic ITCZ is defined between $15^{\circ} \mathrm{W}-37.5^{\circ} \mathrm{W}$. Shown here are three-month running averages. 


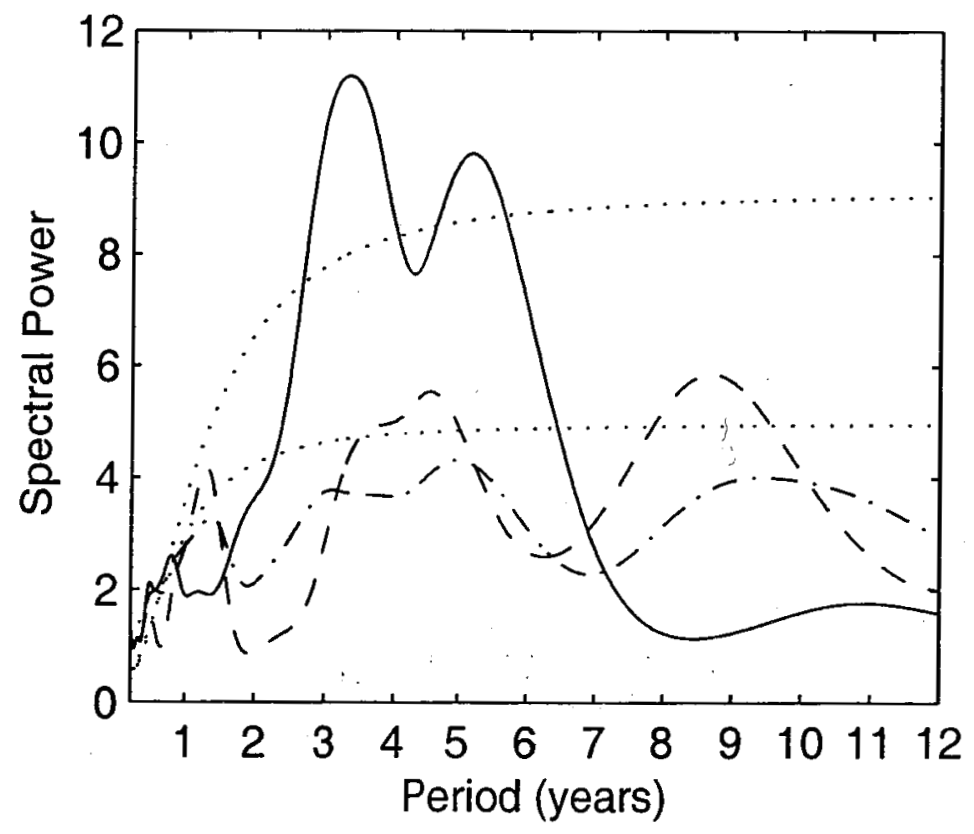

Figure 5: Mean wavelet spectral power of the precipitation anomalies in the center of the Atlantic ITCZ (solid line), the latitudinal position anomalies of the center of the Atlantic ITCZ (dashed line), and the precipitation anomalies averaged over $17.5^{\circ} \mathrm{S}-22.5^{\circ} \mathrm{N}, 15^{\circ} \mathrm{W}-$ $37.5^{\circ} \mathrm{W}$ (dashdot line). Also shown are the red noise spectra (dotted lines) for solid and dashed lines, respectively, computed from the lag-one autocorrelation. 
(a)

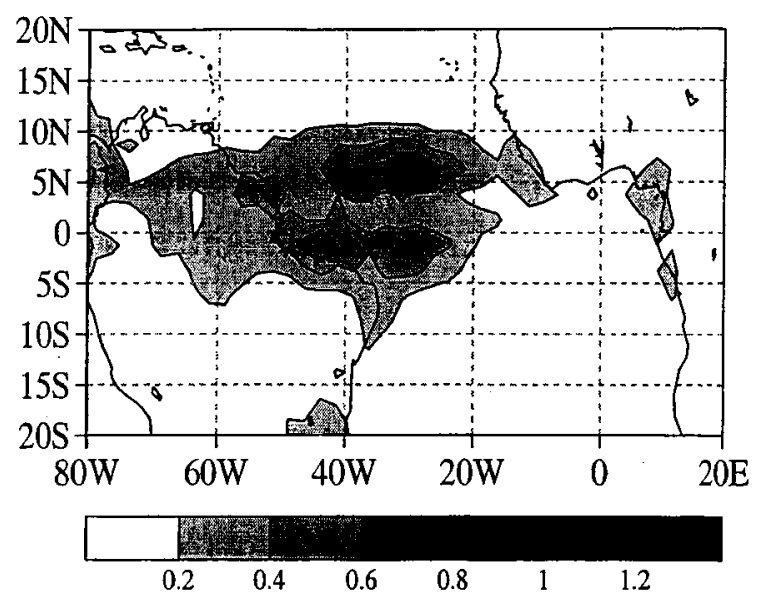

(b)

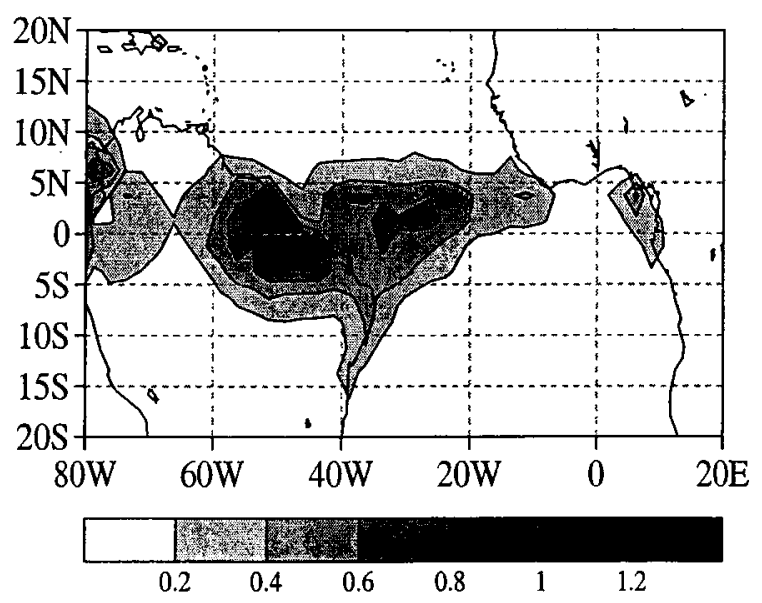

(c)

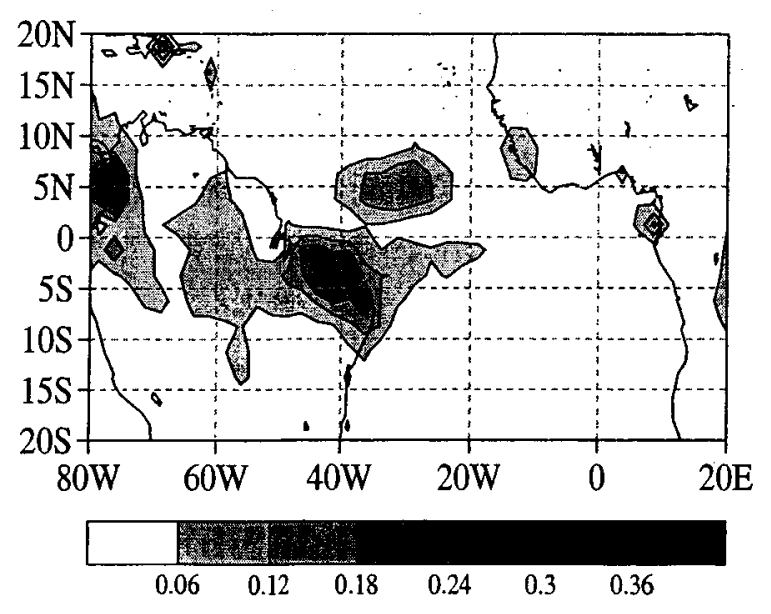

Figure 6: Variances of precipitation anomalies $\left(\mathrm{mm}^{2} d a y^{-2}\right)$ in the tropical Atlantic within various period ranges: (a) $1-2$ years, (b) $2-6$ years, and (c) $6-12$ years. 
(a) Variance of $\mathrm{Pt}_{\mathrm{dm}}$

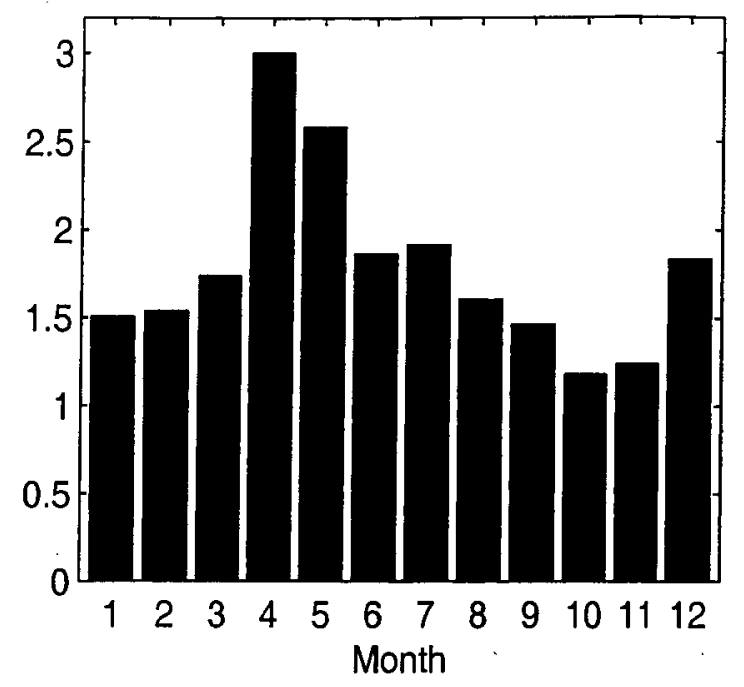

(c) Variance of Lat ${ }_{\text {tcz }}$

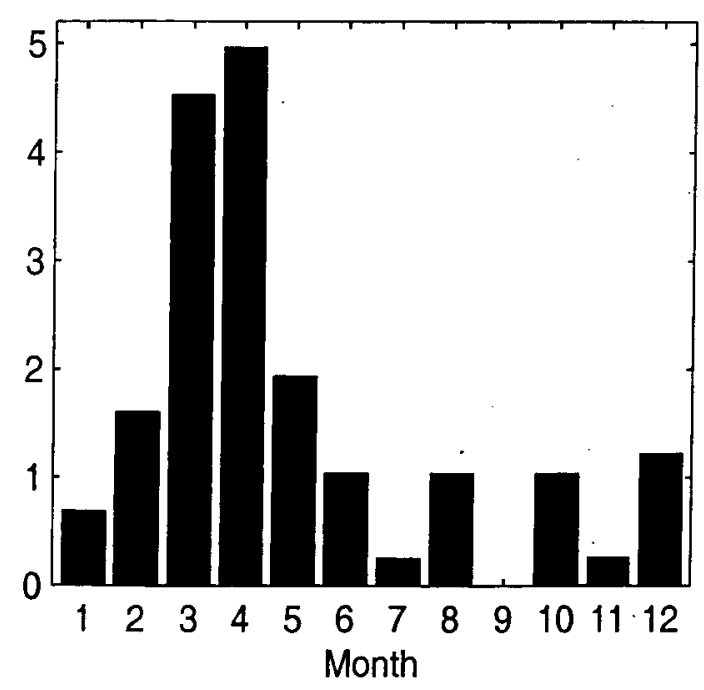

(b) Variance of $P_{\text {itcz }}$

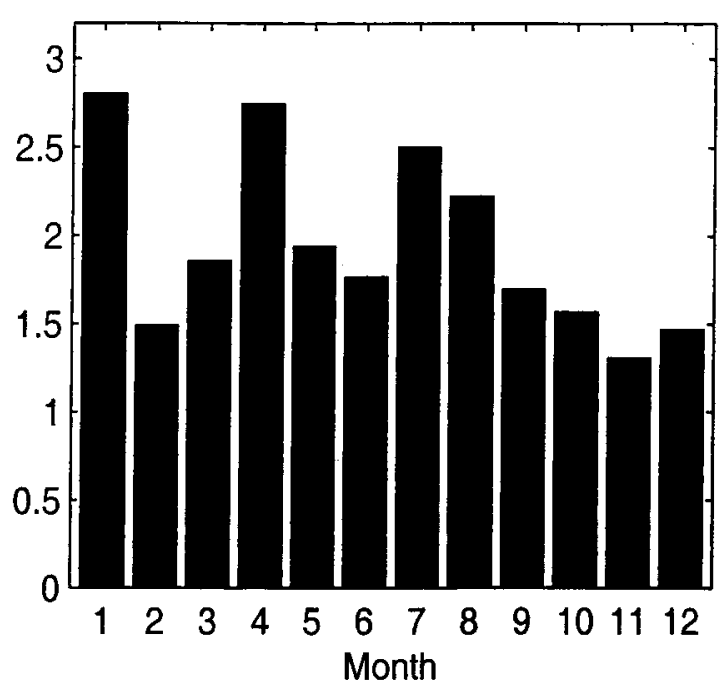

Figure 7: (a) Variance of the precipitation anomalies averaged over $17.5^{\circ} \mathrm{S}-22.5^{\circ} \mathrm{N}, 15^{\circ}-$ $37.5^{\circ} \mathrm{W}$, (b) variance of the precipitation anomalies in the center of the Atlantic ITCZ, and (c) the latitudinal anomalies of the Atlantic ITCZ as a function of month. 


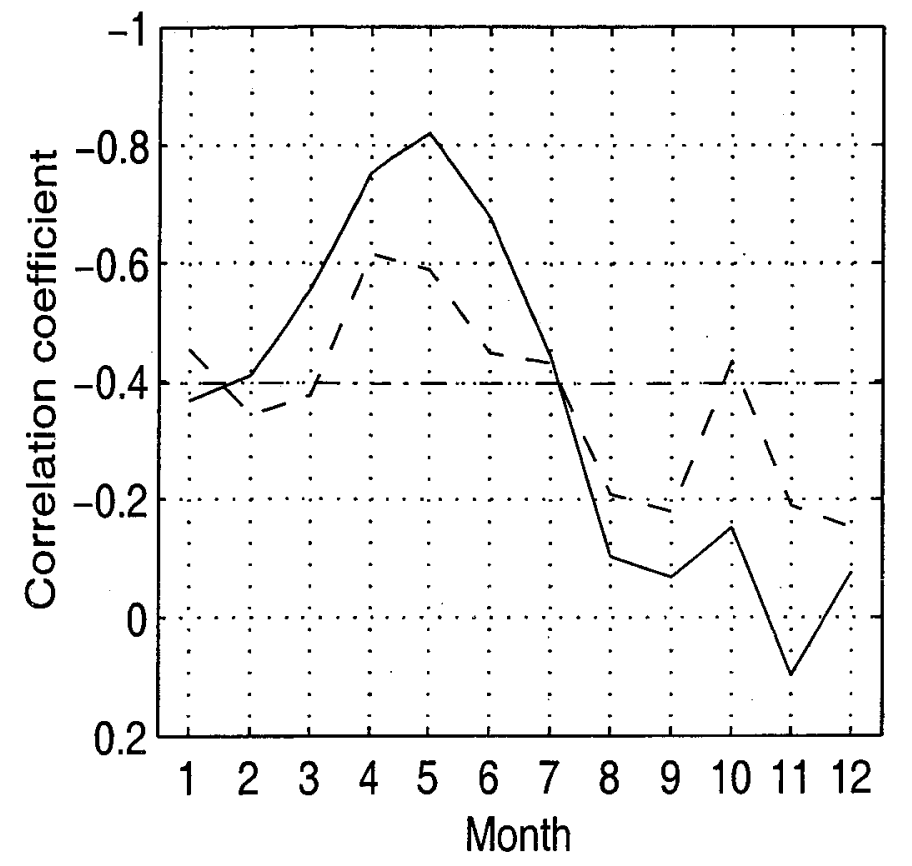

Figure 8: Linear correlation between the precipitation anomalies averaged over $17.5^{\circ} S-$ $22.5^{\circ} \mathrm{N}, 15^{\circ}-37.5^{\circ} \mathrm{W}\left[P_{d m}\left(\mathrm{~mm} d a y^{-1}\right)\right.$; solid line $]$ and in the center of the Atlantic ITCZ $\left[P_{i t c z}\left(m m d a y^{-1}\right)\right.$; dashed line], and the Atlantic ITCZ's latitudinal anomalies (Lat $\left.t_{i t c z}\right)$. $\gamma= \pm 0.4$ denotes the $5 \%$ confidence level based on 23 degrees of freedom $(d o f)$. 
(a)

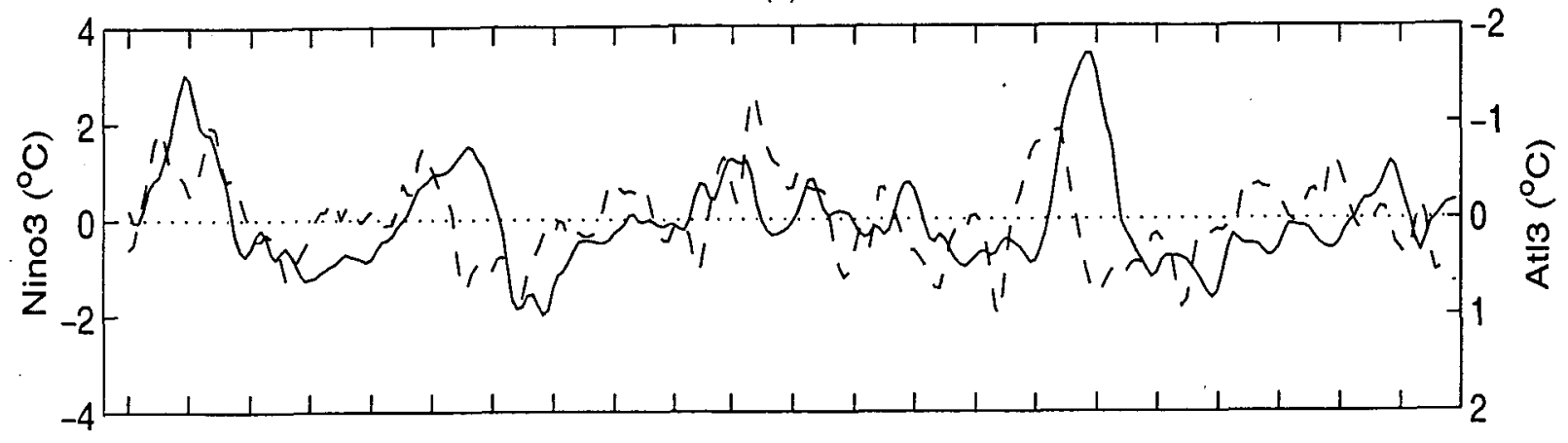

(b)

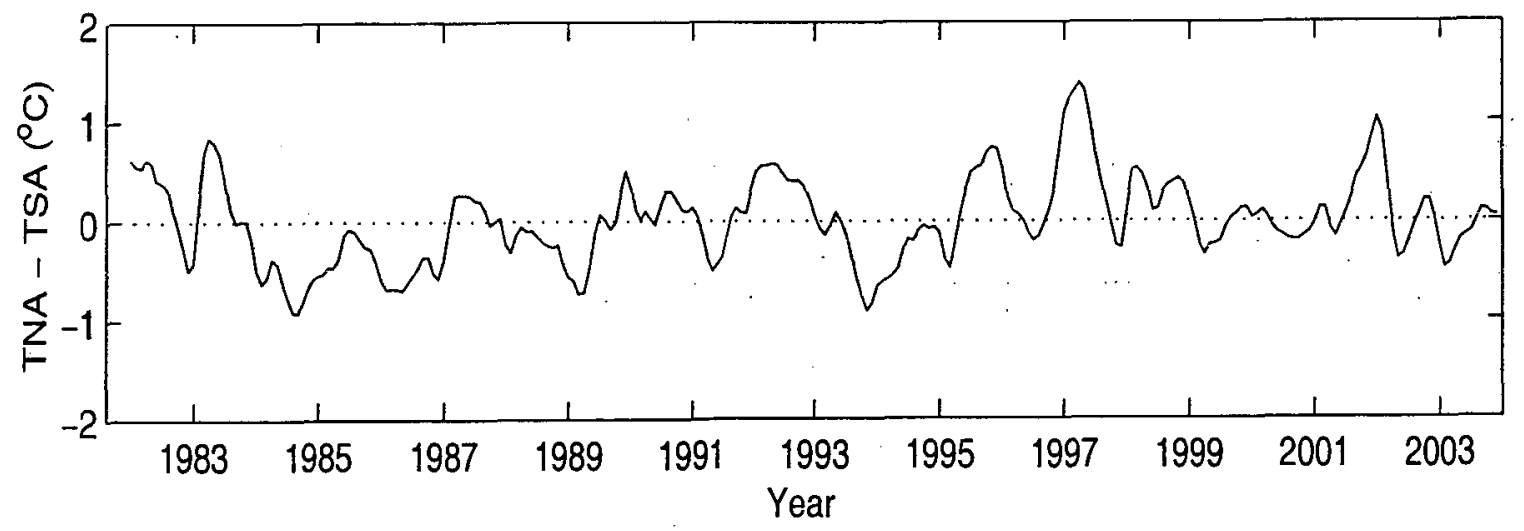

Figure 9: (a) The SST anomalies $\left({ }^{\circ} \mathrm{C}\right.$ ) represent the eastern Pacific Niño3 mode (Nino3; solid line) and the Atlantic equatorial mode (Atl3; dashed line); (b) the SST anomaly difference $\left({ }^{\circ} \mathrm{C}\right)$ between the tropical north and south Atlantic oceans (TNA-TSA) represents the interhemispheric gradient mode. Three-month running average is applied. 
(a)

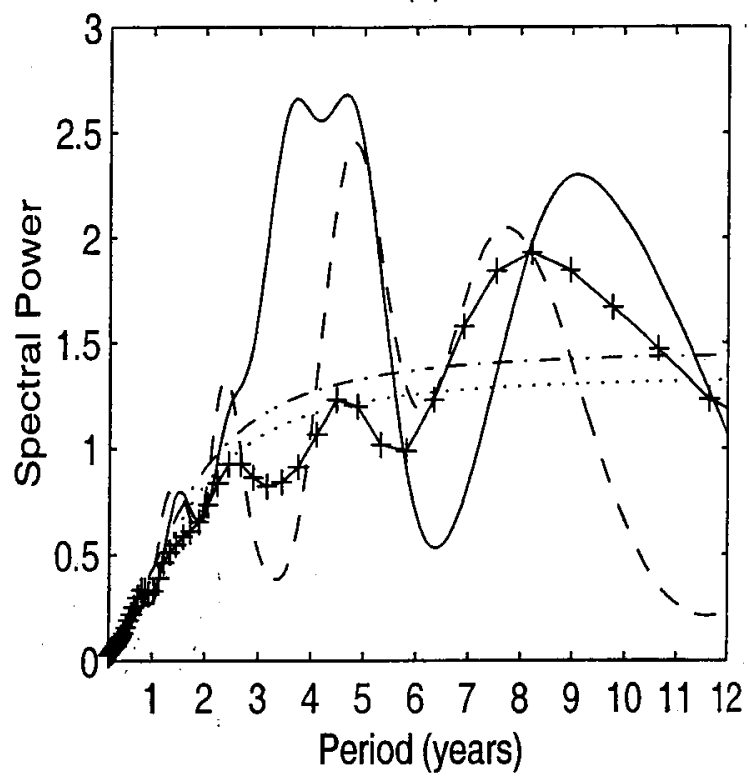

(b)

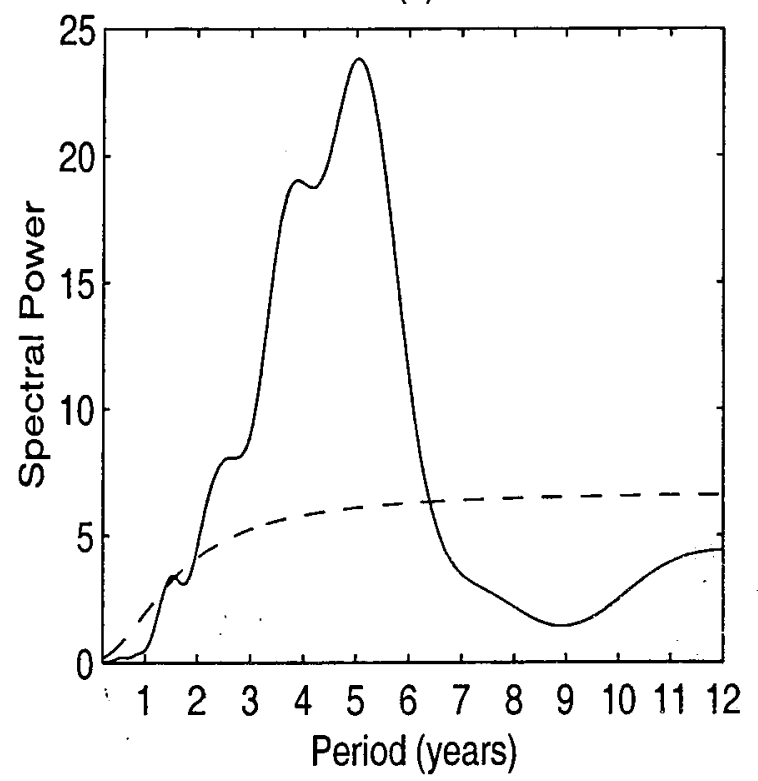

Figure 10: Mean wavelet spectral power of (a) the Atlantic equatorial mode (Atl3; solid line; dashdot line is the red spectrum) and the Atlantic gradient mode (TNA-TSA; dashed line; dotted line is the red spectrum), and (b) the Niño 3 SST anomalies (Nino3; solid line; dashed line is the red spectrum). The cross line in (a) denotes the mean spectral power of SST anomalies over $20^{\circ} S-20^{\circ} \mathrm{N}, 16^{\circ} \mathrm{W}-38^{\circ} \mathrm{W}$. 
(a)

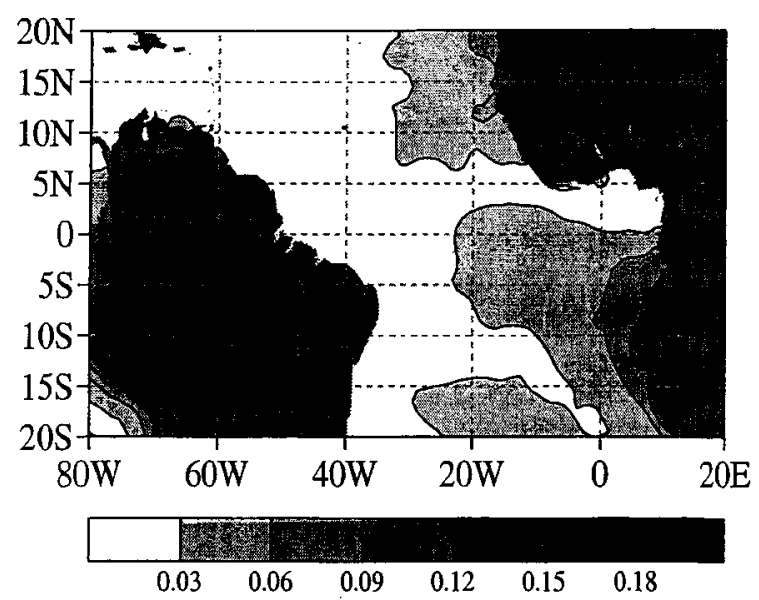

(b)

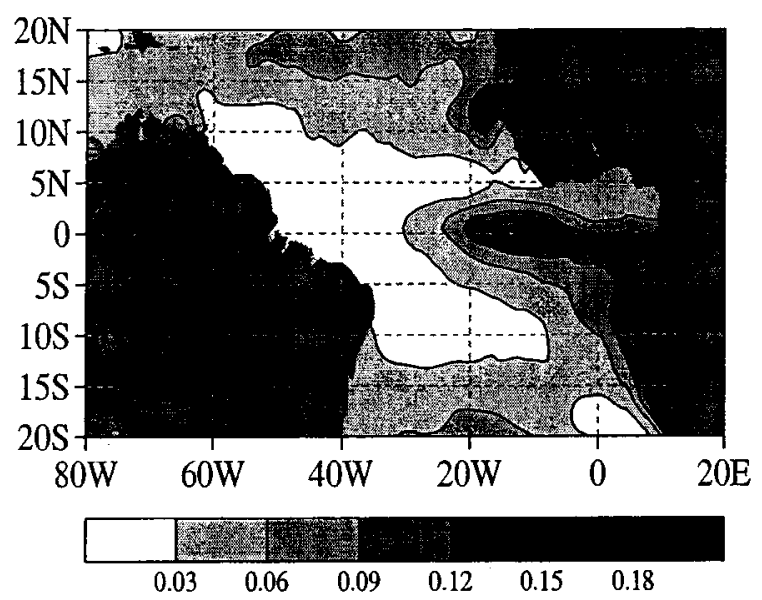

(c)

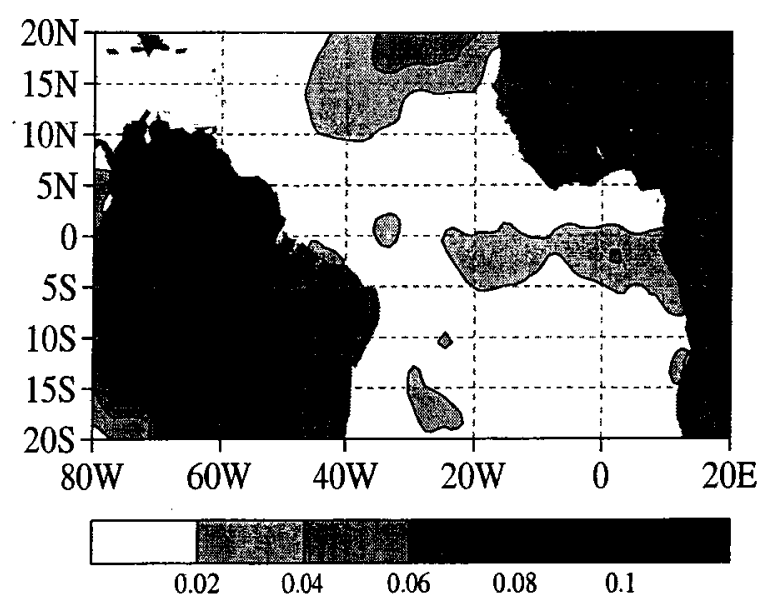

Figure 11: Variances of SST anomalies in the tropical Atlantic within various period ranges: (a) $1-2$ years, (b) $2-6$ years, and (c) $6-12$ years. 
(a) Nino3 \& Atl3

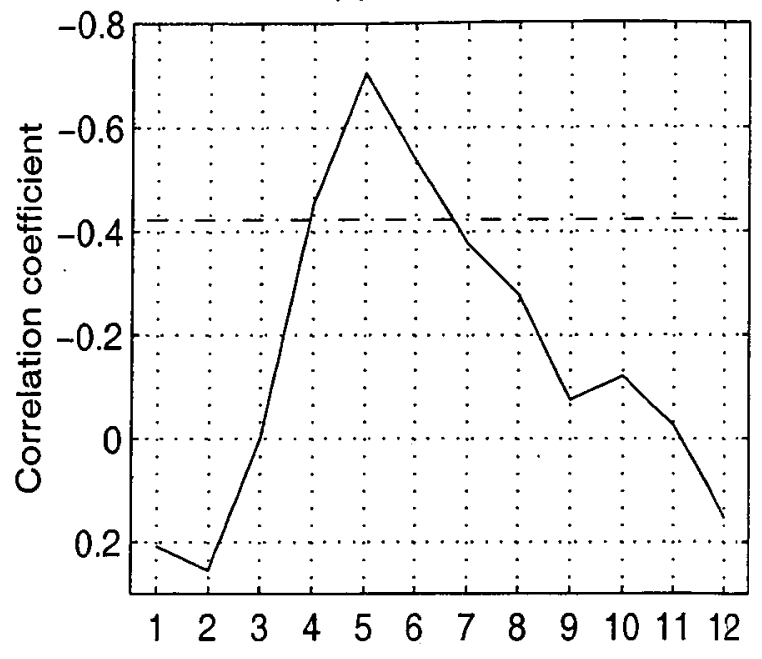

(c) Atl3 \& TNA - TSA

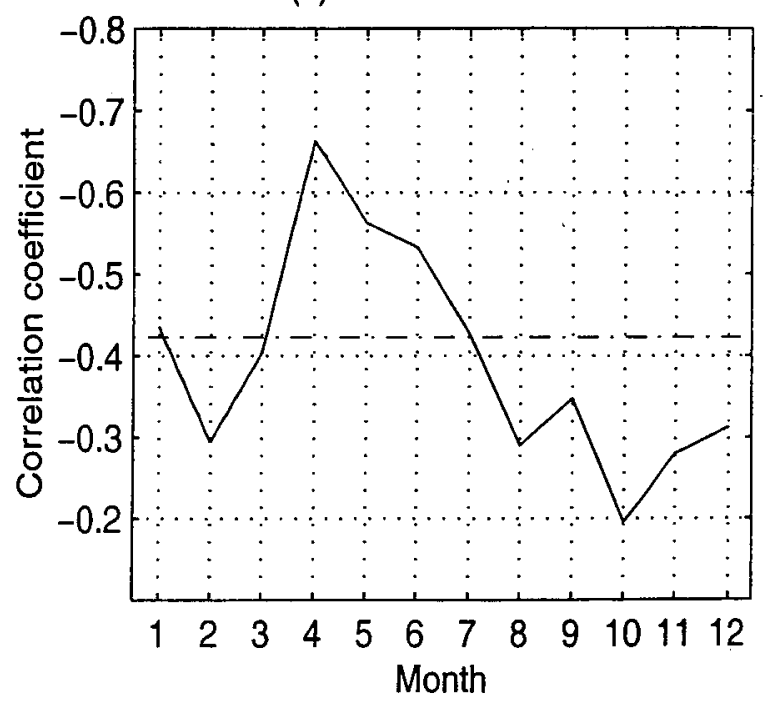

(b) Nino3 \& TNA - TSA

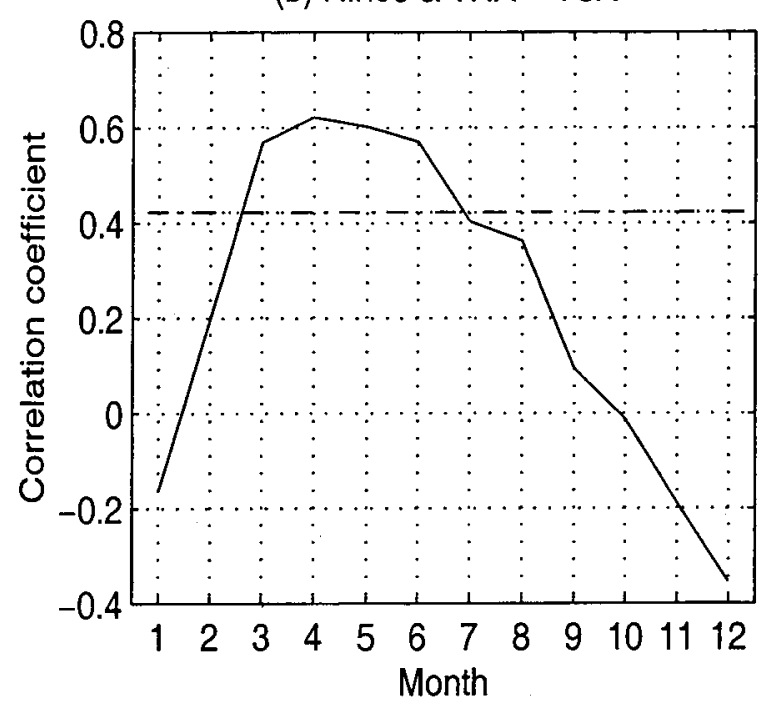

Figure 12: Linear correlation between (a) Nino3 and Atl3, (b) Nino3 and TNA - TSA, and (c) Atl3 and TNA - TSA. Dashdot lines denote the 5\% confidence level based on 20 degree of freedom $(d o f)$. 
(a) Nino3

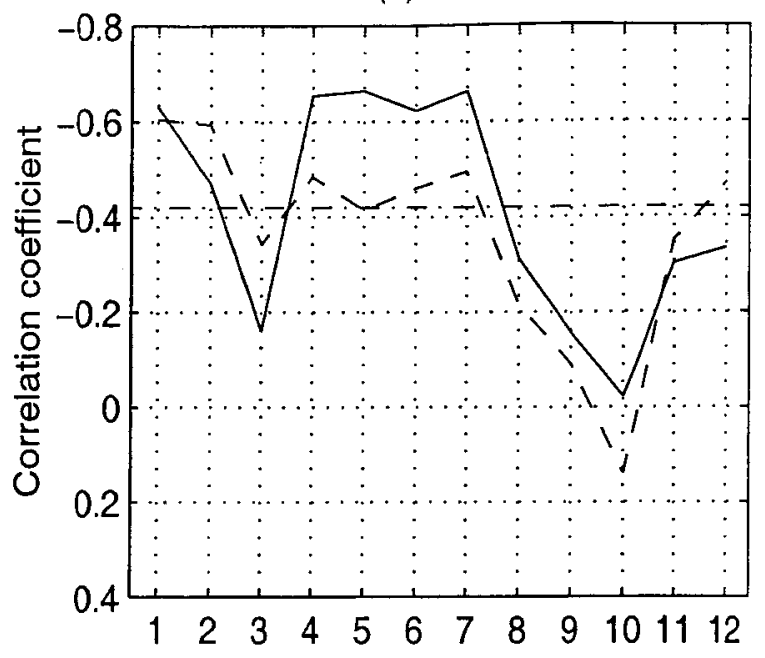

(c) TNA - TSA

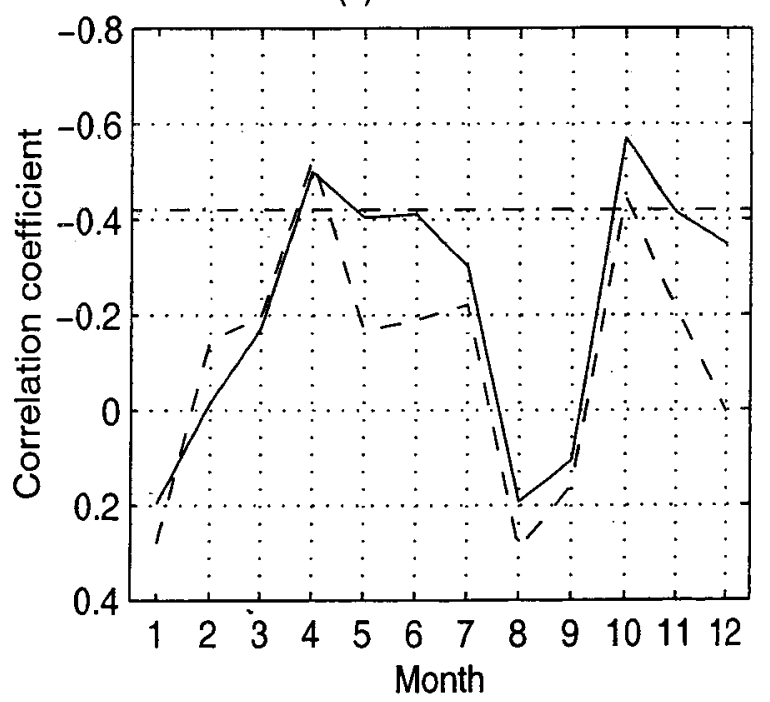

(b) Atl3

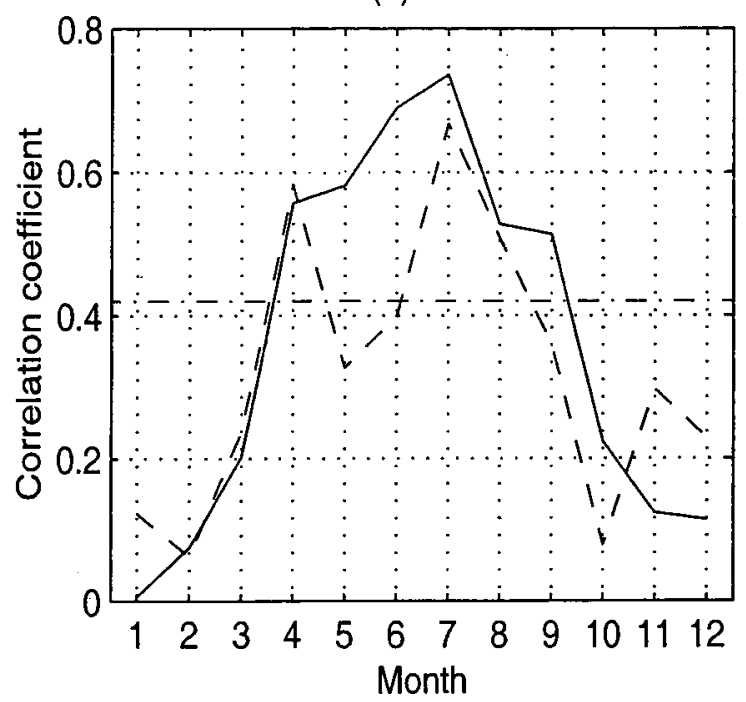

Figure 13: Linear correlation between the precipitation anomalies averaged over $17.5^{\circ} S-$ $22.5^{\circ} \mathrm{N}, 15^{\circ} \mathrm{W}-37.5^{\circ} \mathrm{W}\left[P_{d m}\left(\mathrm{~mm} d a y^{-1}\right)\right.$; solid lines $]$ and in the center of the Atlantic ITCZ $\left[P_{i t c z}\left(m m d a y^{-1}\right)\right.$; dashed lines], and the SST anomalies $\left({ }^{\circ} \mathrm{C}\right)$ representing (a) the eastern Pacific Niño 3 mode (Nino3), and the Atlantic equatorial modes: (b) Atl3 and (c) TNA TSA. $\gamma= \pm 0.42$ denotes the $5 \%$ confidence level based on 20 degree of freedom (dof). 
(a) Lat ${ }_{\text {itcz }} \&$ Nino3

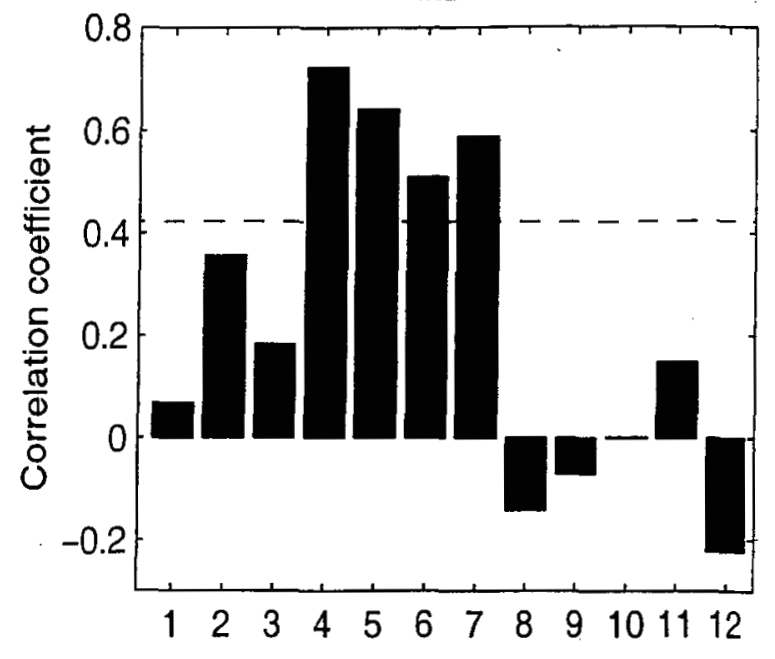

(c) Lat itcz $_{\text {INA }}$ - TSA

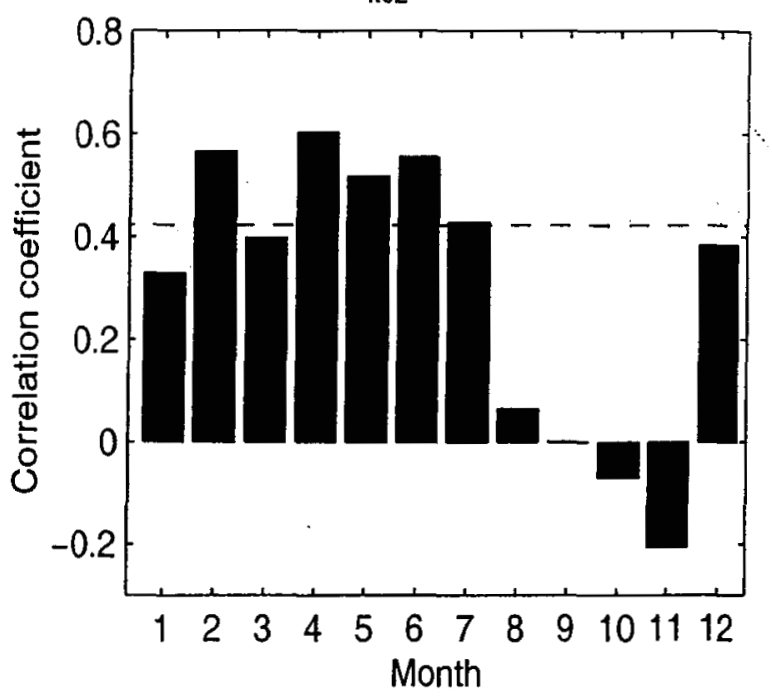

(b) Lat $\&$ itcz Atl3

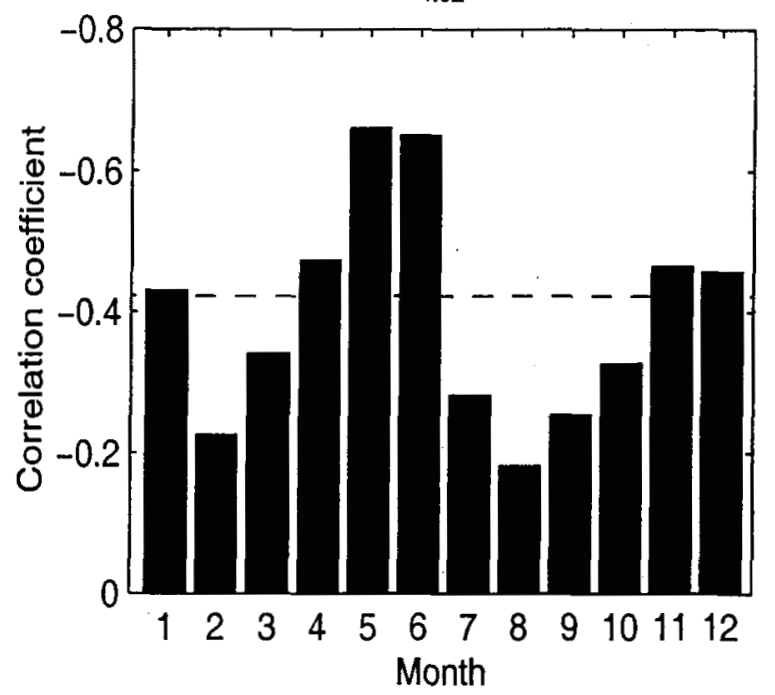

Figure 14: Linear correlation between the latitudinal anomalies of the center of the Atlantic ITCZ ( Lat $_{i t c z}$ ), and the SST anomalies representing (a) the eastern Pacific Niño 3 mode (Nino3), (b) the Atlantic equatorial mode (Atl3) and (c) the Atlantic gradient mode (TNA - TSA). Dashed lines denote the $5 \%$ confidence level based on 20 degree of freedom (dof): 

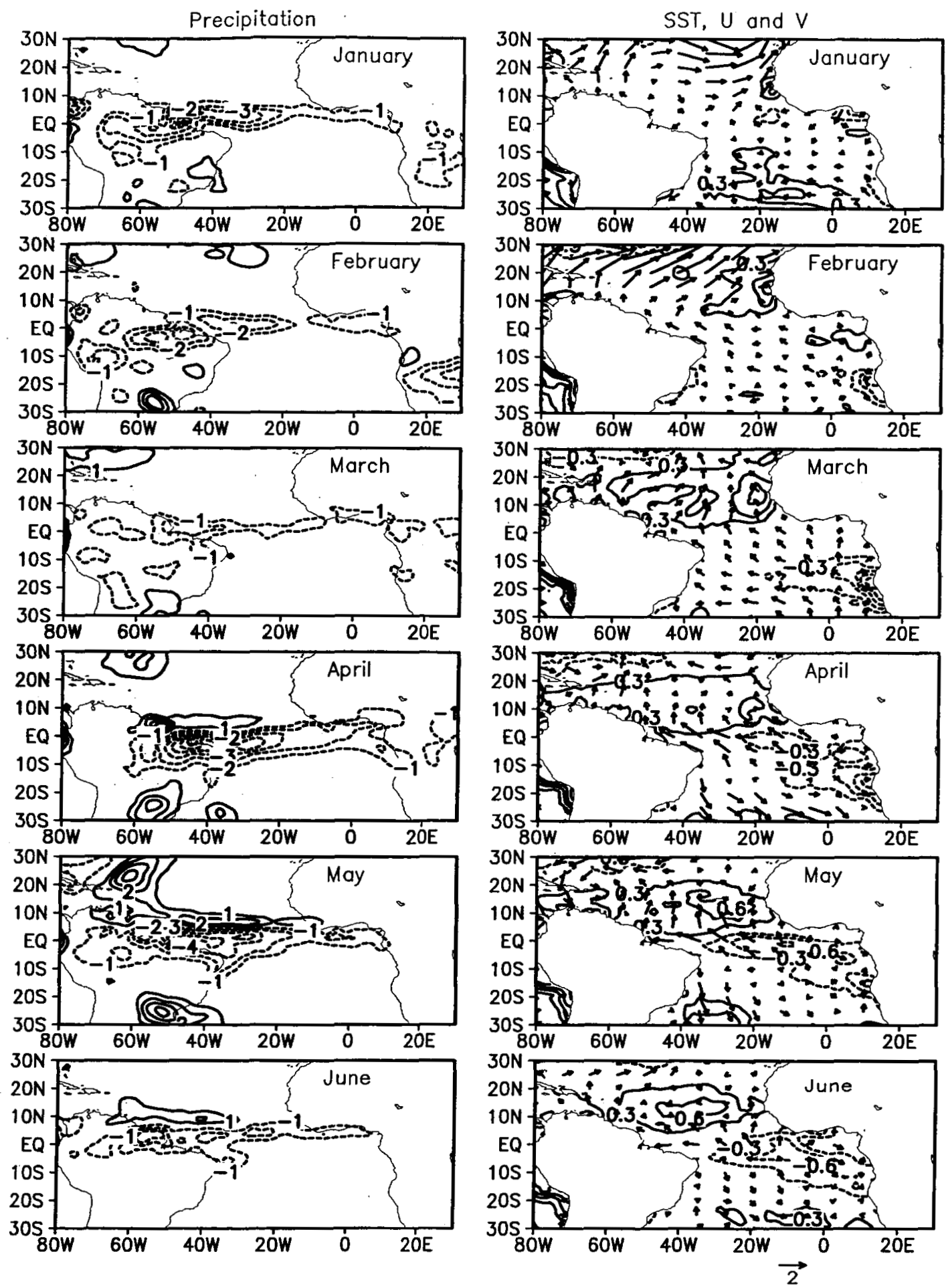

Figure 15: Anomaly composite maps corresponding to the eastern Pacific equatorial mode during January-May (1983, 1987, 1992, and 1998). Left panel is for precipitation anomalies (contour interval $1 \mathrm{~mm} \mathrm{day}^{-1}$ ); Right panel for SST (contour interval $0.3^{\circ} \mathrm{C}$ ) and $1000 \mathrm{mb}$ wind vector $\left(\mathrm{m} \mathrm{s}^{-1}\right)$ anomalies. Positive (negative) anomalies are solid (dashed). The unit of winds is $m \mathrm{~s}^{-1}$. 

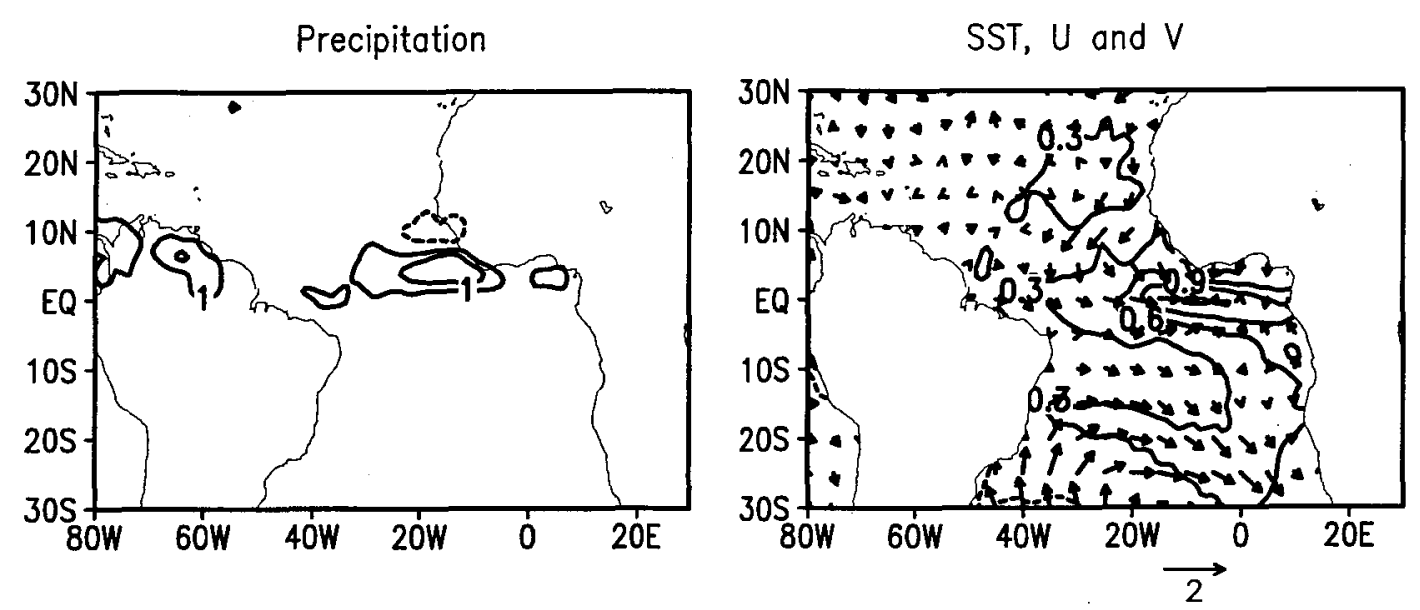

Figure 16: Anomaly composite maps corresponding to the warmest months in the eastern Atlantic (1984, 1987, 1988, 1995, 1996, 1998, 1999, and 2003). Contour intervals are $1 \mathrm{~mm}$ $d a y^{-1}$ for rainfall anomalies and $0.3^{\circ} \mathrm{C}$ for SST anomalies, respectively; Positive (negative) anomalies are solid (dashed). The unit of winds is $\mathrm{ms}^{-1}$. 
1987
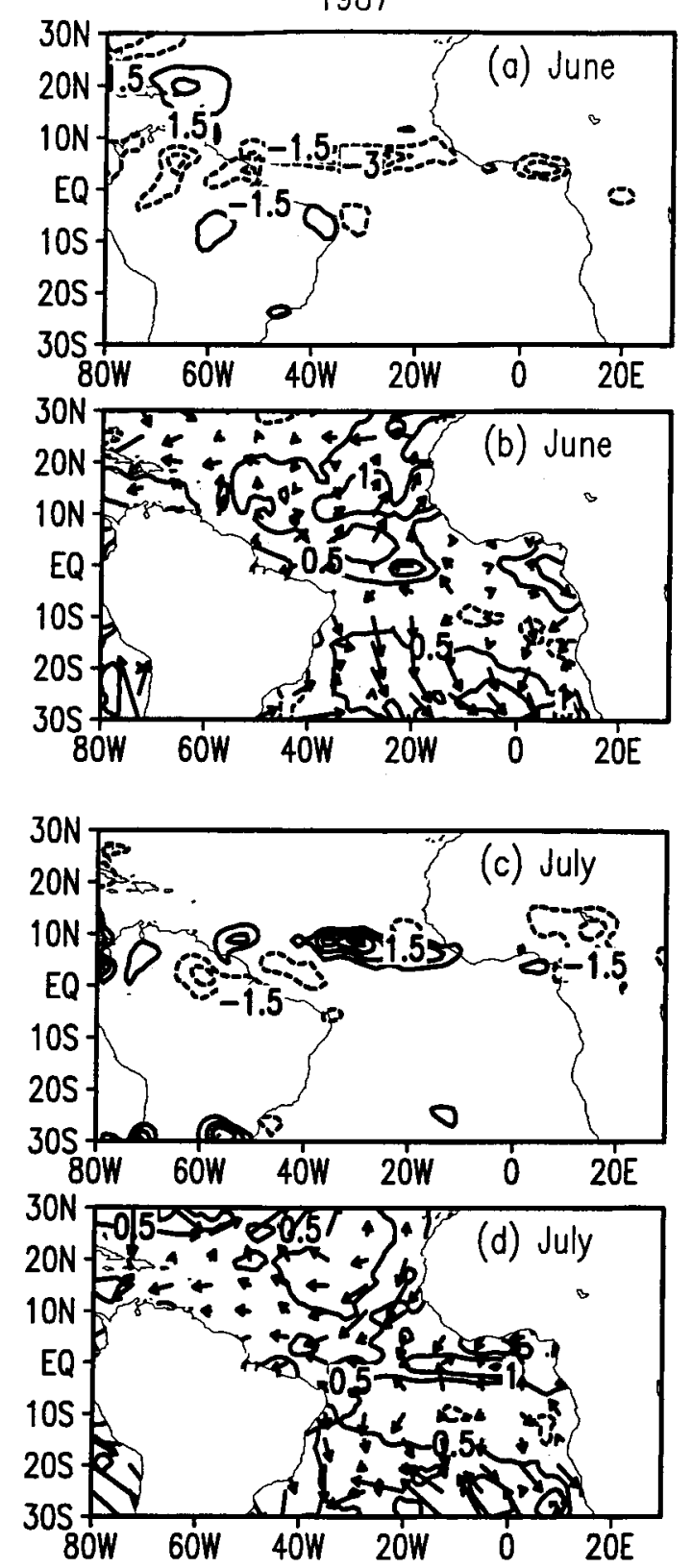

1988
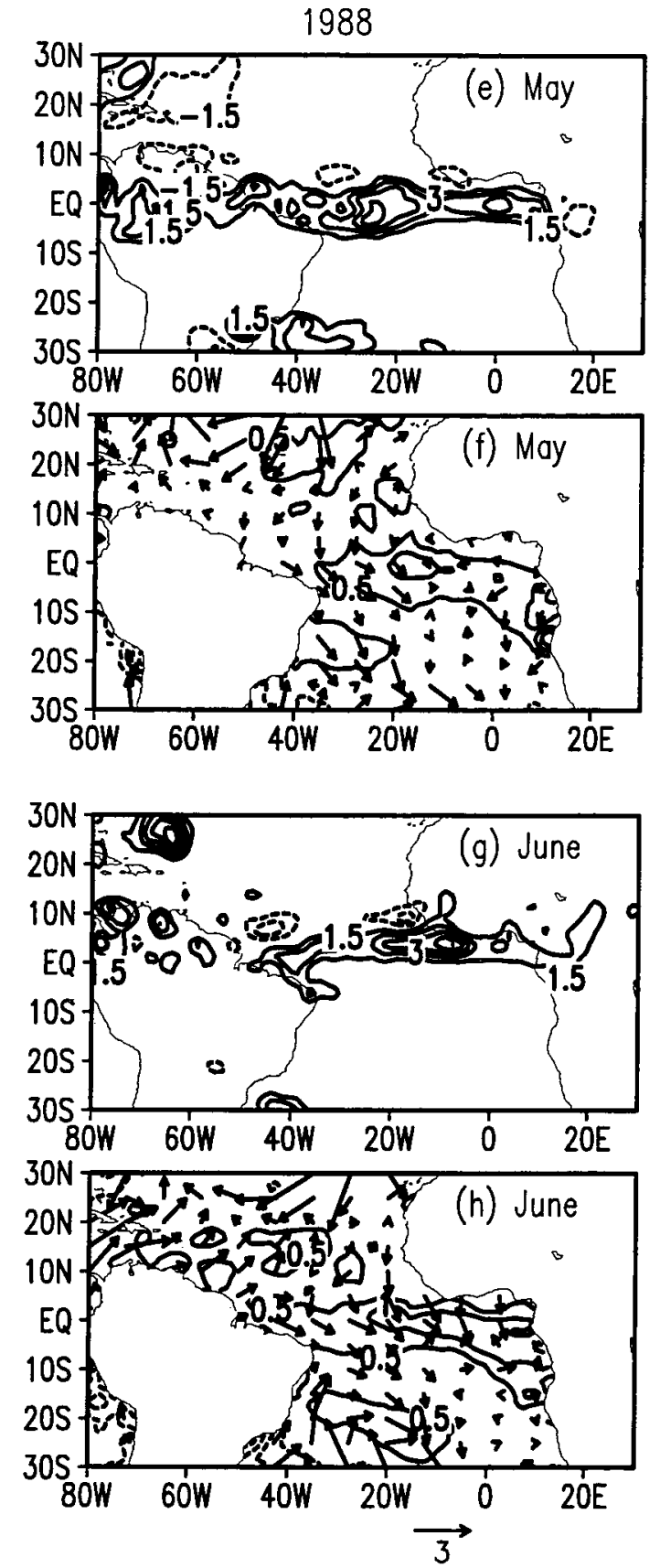

Figure 17: Anomaly maps in 1987 and 1988. The warmest months are July in 1987 and June in 1988. Contour intervals are $1.5 \mathrm{~mm} \mathrm{day}^{-1}$ for rainfall anomalies (a, c, e, and g) and 0.5 ${ }^{\circ} \mathrm{C}$ for SST anomalies (b, $\mathrm{d}, \mathrm{f}$, and $\mathrm{h}$ ), respectively; Positive (negative) anomalies are solid (dashed). The unit of winds is $m s^{-1}$. 


\title{
Interannual Rainfall Variability in the Tropical Atlantic Region
}

\author{
Guojun Gu and Robert F. Adler
}

\section{Popular Summary}

Using a 25-year (1979-2003) monthly rainfall dataset from the Global Precipitation Climatology Project (GPCP), this study investigates interannual variability in the tropical Atlantic region. Evident seasonal cycle exists in both the basin-mean rainfall and the intertropical convergence zone (ITCZ) usually seen as a narrow band of intense convection and rainfall in the tropics. The ITCZ becomes strongest as moving to the northernmost latitude $\left(8^{\circ} \mathrm{N}-10^{\circ} \mathrm{N}\right)$ during July-September when most rainfall is observed in the entire tropical Atlantic basin; it becomes weakest during January-February as moving back to the south and approaching the equator, with the total rainfall in the basin being the least. In contrast, the strongest interannual rainfall variability (year-to-year variation) occurs during March-May when the ITCZ becomes weaker and tends to be near the equator, not during the season (July-September) when it becomes strongest.

Interannual rainfall variability is further found to be closely related to the Pacific El Niño/ La Niña (anomalous warm/cold tropical central-eastern Pacific) events, besides being effectively forced by two local sea surface temperature (SST) fluctuations, i.e., the Atlantic equatorial (or Atlantic Niño) and interhemispheric SST gradient modes. El Niño (La Niña) is usually followed by evident decrease (increase) in the Atlantic ITCZ strength and the total rainfall amount in the tropical Atlantic basin. Furthermore, the two local SST fluctuation modes are highly correlated to the Pacific El Niño/ La Niña events, particularly during spring and early summer season. Thus, to correctly quantify and diagnose Atlantic climate variability, the remote impact from the Pacific has to be first assessed. Due to the internal relationship of rainfall and other climate variables, this observational study will improve our understanding of climate variability in the tropical Atlantic and neighboring continents, such as anomalous Atlantic hurricane activity, and droughts/floods over West Africa and South America. 